Historic, Archive Document

Do not assume content reflects current

scientific knowledge, policies, or practices. 

6273

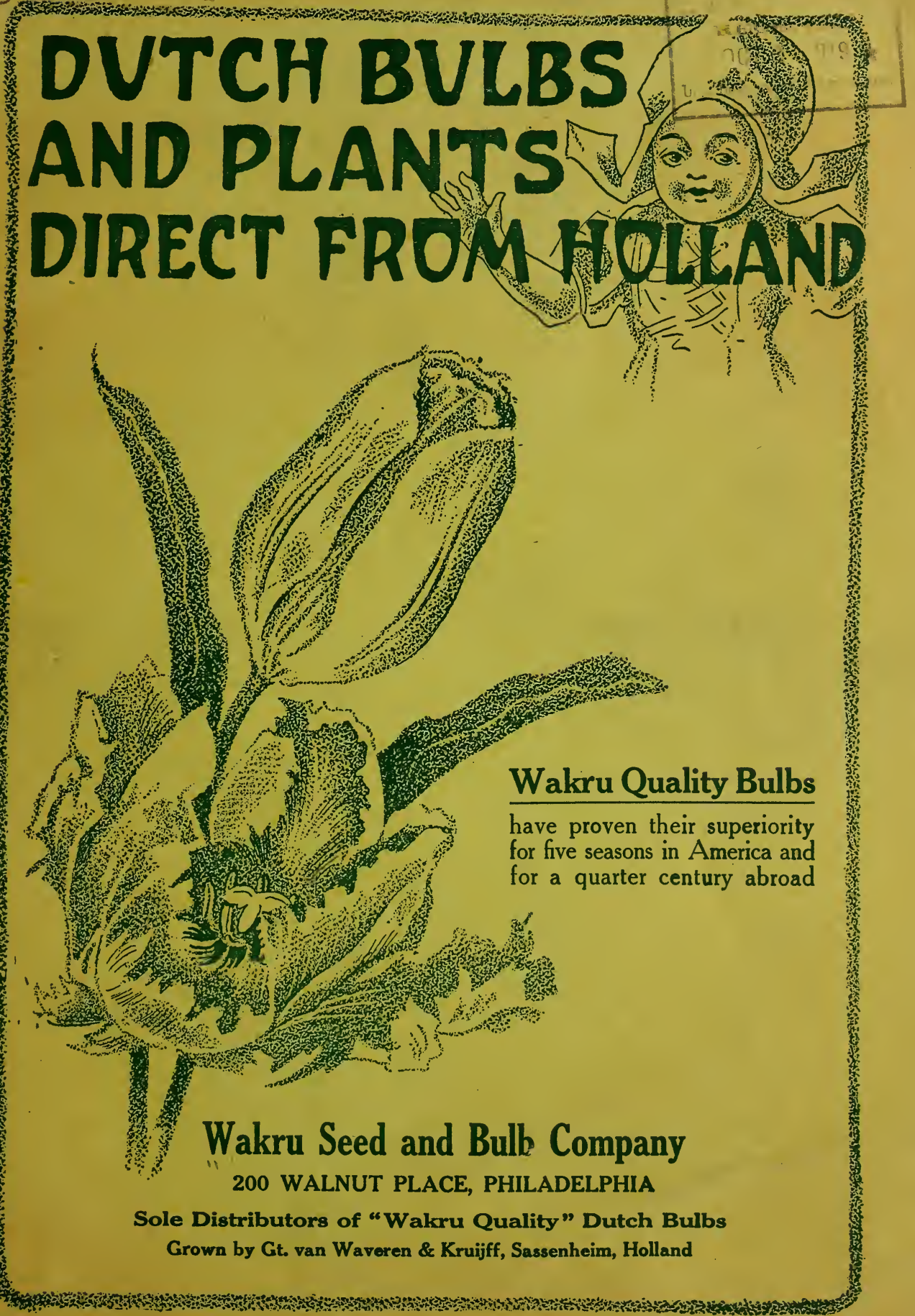




\section{Dutch Bulbs
and Plants
Direct from Holland}

This is our

Fifth Annual

Catalog

Add 3 Months

to your

Garden

Order Now

to get

Better Bulbs
Before the first catalog selling Wakru Bulbs direct to the American Garden Lover, Gt. van Waveren \& Kruijff had for 44 years been known as leading growers of best quality bulbs. Next year the firm celebrates its fiftieth anniversary.

Before the trees open their leaves in spring, your garden can be brightened only by crocus, tulips, hyacinths, daffodils, etc. - planted in fall.

To get the best bulbs, in time for planting before frost, order now! This assures greater satisfaction, because every bulb you get by our direct-from-Holland method, is the finest selection from the best bulbfields in Holland, packed there and shipped to your home in the original package. We list no experiments-all varieties proved by our testing grounds, both in Holland and in America.

True to

Name and Color

Every re-packing lessens the chance of getting bulbs true to name and color. We eliminate all re-packing by direct shipment in original packages. We assist you in selecting proper combinations for plantings. Our American manager is a practical Hollander, whose whole life has been spent in raising bulbs.

Grown

Wherever

Tested
Our records show that wherever test orders for Wakru Bulbs have been secured, the next season brought us largely increased orders. Letters from all over America prove this-a few extracts within.

Do not delay. Make up your test order today. Judge us by the result in your own garden.

(All orders accepted with privilege of returning monoy if war in Europe prevents shipment.)

\section{WAKRU SEED AND BULB CO.}

200 Walnut Place,

Philadelphia, Pa., U. S. A.

Other Branches: Moscow, Russia; Leipsic, Germany; Buenos Ayres,

Argentine Republic; London, England; Gutenburg, Sweden.

Note the new, reduced prices in this catalog.

100 prices apply down to 25 , of any one variety;

1000 prices down to 250 


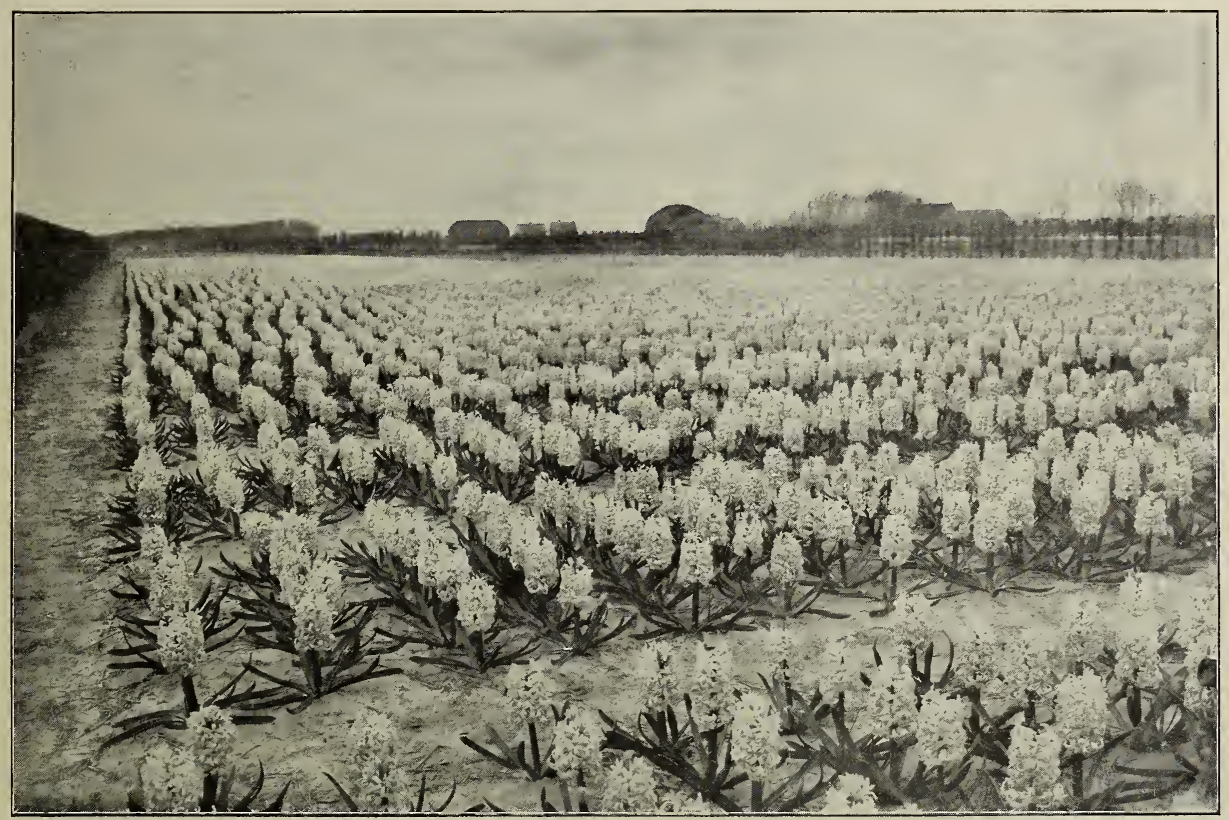

I Section of our Fields in Holland.-Hyacinths above-Tulips below.

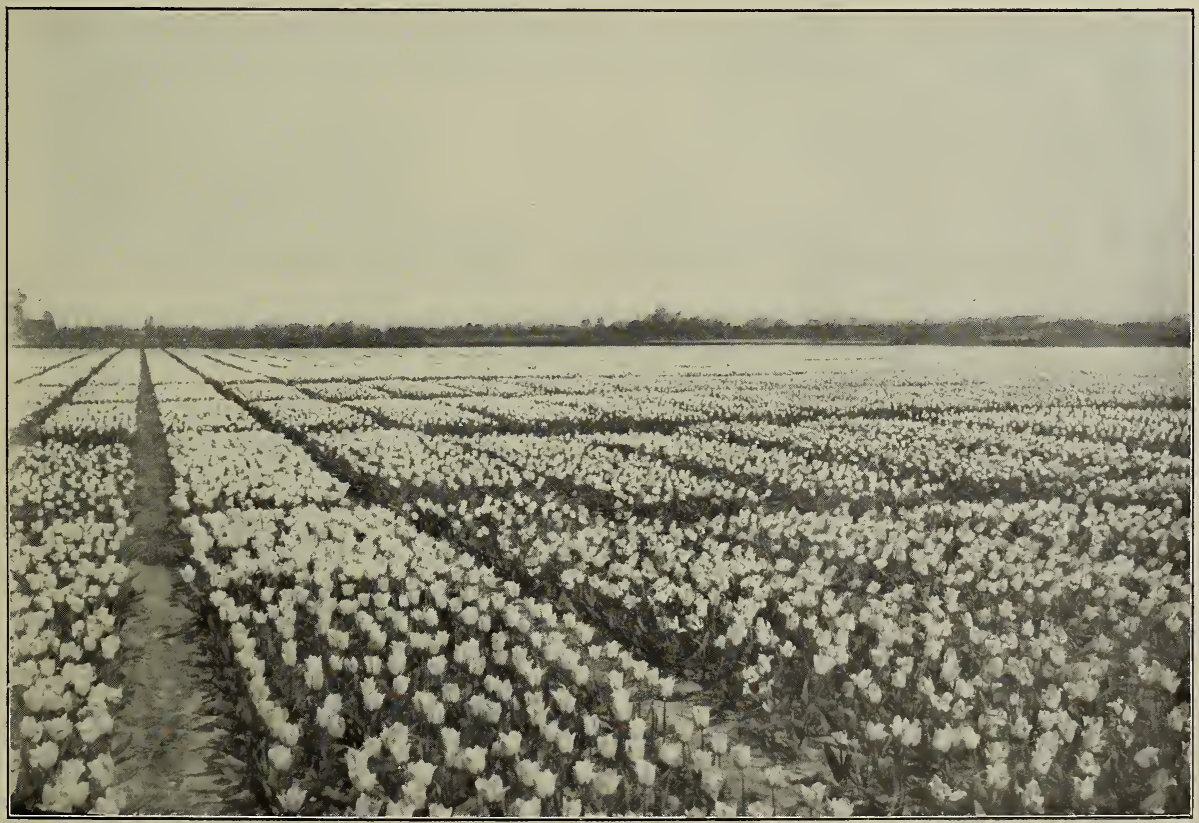

"Wakru Bulbs-the Sign of Quality." 


\section{How to grow Bulbs Outdoors}

GARDEN BULBS. A garden may be small or large, yet can always be made to look attractive in the spring with Dutch bulbs when no other flowers have yet made their appearance. The trees will just have begun to show a sprinkle of the tenderest green and the lawn will have assumed a more lively tint when the balmy air already is fragrant with the perfumes of the Dutch flowers.

CROCUS. These may be scattered all over the lawn. They will stand a lot of rough handling and yet show up cheerfully in the early spring. Plant them a couple of inches deep, single or in little groups.

SNOWDROPS may be treated in the same way and certainly repay for the little money and trouble bestowed on them.

HYACINTHS. A splendid display of these typical Dutch bulbs can be made by putting them in beds. Pick out the location for your bed which can be made oblong, round, or square or any shape, according to taste. An oval bed of about $11 \frac{1 / 2}{2}$ feet by $7 \frac{1}{2}$ feet will require about 300 bulbs, while 100 bulbs make an excellent showing in an oblonged bed $21 / 2$ by 7 feet. Plant them six inches deep and six inches apart. It will be well to pay attention to the various color combination we are giving under the heading "first size Hyacinths." We might say that the second size as well as Bedding suit the purpose of planting outdoors just as well as the first size and will not run into such a high cost.

TULIPS are also ideal for bedding purpose in such the same manner as the Hyacinths. They should be planted about four inches deep and four inches apart. It is, however, very important to put the right kinds and shades in one bed, as all varieties do not flower at the same time and height. Our little guide will help you to pick out the right varieties (see Tulips).

NARCISSUS. While Hyacinths and Tulips like to have plenty of Sunshine, Narcissus are well contented with shady places. Along hedges, and around and between evergreen they show up fine. They are not very particular as to the depth at which they are planted.

\section{The Three Cardinal Points in Planting Bulbs are these:}

First, - as early as permissible in October-to give the bulbs ample chance to make roots before winter comes.

Second, to plant at the hight depth, as noted hereafter under the various classes; it is particularly desirable that formal beds should be planted at an even depth.

Third, to provide good drainage if your soil is clayey in character. Bulbs can grow in any average good soil, and in shady places, but like most other flowering plants they benefit by good soil and sun (the latter particularly in the case of Tulips and Hyacinths).

Remember if you are planting bulbs in beds that have contained flowering plants during the summer, that the soil will need enrichening, if you desire a profusion of large blooms.

The ideal treatment for a bulb bed, for the planting of tulips, for instance, is to dig out the top soil to a depth of five inches, an inch deeper than the bottom of the bulb is supposed to come. Take well rotted manure and spade it, along with sand if the soil below is clayey, till you have an underlying layer of nearly a foot in depth which is rich and open in texture, so that the bulbs can make a good root growth and find plenty of food when the time comes to send up their flower spikes in spring.

Level off the top of this Iayer, or if the bed when completed is to be crowned, crown this surface so that all bulbs may be planted at an even depth. Spread practically an inch of sand above this layer; or place it directly below each bulb; set bulbs with flat (or root face) down; then fill in the top soil and press lightly-this little extra care will insure the roots taking hold so much more easily, will provide ample drainage in case there should be a heavy rain shortly after planting, and thus prevent rotting of the bulbs.

\section{Collections for Outdoors. All First Sized Bulbs}

Bulbs will bloom from February to June, as:

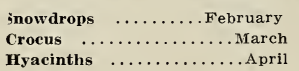

E at $\$ 2.50$

24 Hyacinths, red, rose, white and blue separate.

24 Single Tulips, red rose, white and yellow separate.

50 Crocus, white, yellow, blue and striped separate.

24 Single Narcissus, white and yellow.

24 Spanish Iris, yellow, white, light and dark blue.

12 Snowdrops (Galanthus Nivalis).

F at $\$ 5.00$.

48 Hyacinths, red, rose, white and blue separate.

48 Single Tulips, red, rose, white and yellow separate.

100 Crocus, white, yellow, blue and striped separate.

48 Single Nareissus, white and yellow.

12 Double Narcissus, white.

48 Spanish Iris, yellow, white, light and dark blue separate.

24 Snowdrops (Galanthus Nivalis).

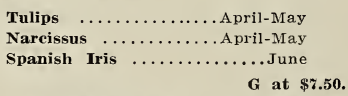

i2 Hyacinths, red, rose, white and blue separate.

72 Single Tulips, red, rose, white and yellow separate.

150 Crocus, white, yellow, blue and striped separate.

72 Single Nareissus, white and yellow separate.

24 Double Narcissus, white and yellow separate.

72 Spanish Iris, yellow, white light and dark blue.

36 Snowdrops (Galanthus Nivalis).

\section{$\mathrm{H}$ at $\mathbf{\$ 1 0 . 0 0}$.}

100 Hyacinths, red, rose, white and blue separate.

100 Single Tulips, red, rose, white and yellow separate.

25 Darwin Tulips, finest mixture.

200 Crocus, white, yellow, blue and striped separate.

100 Single Narcissus, white and yellow.

25 Double Narcissus, white arpl yellow.

100 Spanish Iris, yellow, white, light and dark blue separate.

50 Snowdrops (Galanthus Nivalis). 


\section{INDOOR BLOOMING BULBS FOR FORCING}

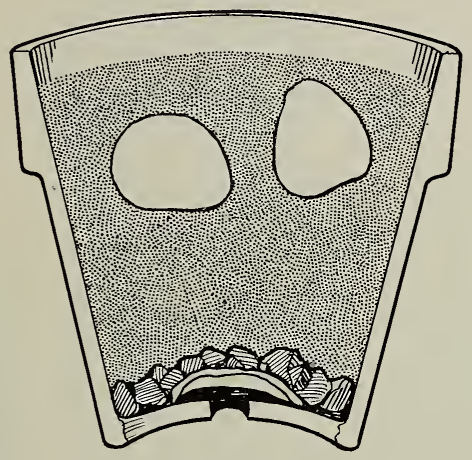

In potting bulbs for indoor blooming, be careful not to plant bulbs too deep. The soil should not come within a half-inch of the top of the pot and the top of the Narcissus bulbs should be up to the surface; the Tulips, not over an inch below; Hyacinths or Crocus, not over a half-inch below.

The soil should be light and rich, three parts loam, one part leaf mould and one part sand is a good combination; the leaf mould serving the purpose of holding the moisture.

A six-inch pot should not contain more than five Tulips, or A six-inch pot should not contain more than five Tulips, or
two Narcissus, or two Hyacinths, or six Crocus. An eight-inch pan will hold ten Tulips, or eight Hyacinths, or eight Narcissus, or twelve Crocuses.

If bulbs are planted in pots, use a piece of a broken pot as an arch over the outlet hole and put in stones to hold this in position and allow drainage without washing away the soil, then on top of this inch of drainage material add coarse, open soil, with the finer soil described above, both above and below the bulbs, as shown in cut.

The bulbs having been potted, they are placed in the cold and dark for a period of a month and a half to three months, being watered only every ten days to prevent the soil from drying up.

It is much simpler if you have garden space to do it, to dig a trench a foot and a half deep, fill in about six inches with ashes, and place the potted bulbs on this layer. Then water well and cover with soll or coal ashes. Unless the season is unusually dry the bulbs will need no further attention till it is time to bring them in. Remember that ample root development is the important point in forcing bulbs. Till the removal of one of the pots from this trench shows that the roots have developed to such an extent that they can be seen through the drainage hole, it is not wise to bring them in through the the leaves will be developed to the point of spreading apart so that the bud ean easily push up and out.

that the bud ean easily push up and out.

Assuming that the bulbs are well rooted, the next point is to be sure that they are not kept in too warm a temperature. An average temperature of 55 degrees is plenty high enough. At no time, especially while the bulb is flowering, should the temperature exceed 60 degrees, if you desire best results. Over three-fourths of the failures in forcing bulbs result from too high a temperature; therefore, beware.

Too much water before rooting and too little water after are the prime causes of failures in raising bulbs. Water plentifully once you have them indoors-remember that the house is dry and warm; that air, light and water are the cheapest things in the world and the most essential to success in indoor bulb culture.

If blooms are being borne on too short flower stems and you know that the root growth is ripe, put an open paper cone about a foot righ and a couple of inches wide at the top, over the top of the bulb. The stem will draw up in the desire to reach the light. This treatment is particularly applicable to Hyathe light
cinths.

\section{WATER CULTURE}

What better winter decoration for the home is there than the fragrant Paperwhite Narcissus, the Dutch Hyacinths, Daffodils and Crocuses?

Any of these can be easily raised in water, in a flat jardiniere which has been partially filled with sand or pebbles. diniere which has been partially filled with sand or pebbles.
Stones between the bulbs will hold them firmly in place, assurStones between the bulbs
ing erect flower spikes.

Hyacinths grow beautifully in glasses specially made for this purpose and obtainable in most flower shops. The Tye kind is the most preferable. Be careful not to let the bottom of the bulb touch the surface of the water. There should be about the thickness of a nicket between. Place the glass in a dark cupboard or closet and wait till the roots crawl over the bottom of the glass. If the water should become foul, let it run out, but never remove the bulb from the glass. Clean the

root by shaking the glass gently after filling again and put in fresh water after the dirt is out. Be careful not to break the roots.

It is well to fill the glasses with soft rain water, and to add a little charcoal from the start, using plant food in the water around blooming time to increase the size of the flowers and the strength of the stem.

A dozen or more Crocuses in a flat bowl make an excellent display, but to assure bloom keep these in an unheated room if possible.

Remember in growing bulbs in water that it is just as essential to get good roots before exposing to the light, as in the case of indoor forcing in soil. Unless there is a good roo growth you are almost sure to be disappointed with the results.

\section{Collections for Indoors.}

\section{A at $\mathbf{\$ 2 . 5 0}$}

6 Hyacinths in six named sorts for pots or glasses,

6 Hyacinths, early Roman, pure white.

12 Single Tulips in four named sorts.

6 Narcissus, Paperwhite, early flowering, very easily grown.

12 Narcissus, single, in four named sorts.

12 Crocus in two colors, can be easily grown on a saucer with water. Keep in a dark place for several weeks till the saucer is well filled with roots. Then bring to the light, but do not place in too warm a spot. Keep saucer well filled with water all the time. If fungus forms, remove by holding saucer under the water tap without removing the bulbs.

\section{$\mathbf{B}$ at $\$ 5.00$.}

12 Hyacinths in twelve named sorts for pots or glasses.

12 Hyacinths, early Roman, pure white.

24 Single Tulips in eight named sorts.

6 Double Tulips in two named sorts.

12 Narcissus, Paperwhite, early flowering.

24 Nareissus, single, in six named sorts.

24 Crocus in four named sorts.

\section{All First Sized Bulbs}

\section{C at $\$ \mathbf{\$ 7 . 5 0}$.}

18 Hyacinths in eighteen named sorts for pots or glasses.

18 Hyacinths, early Roman, pure white.

36 Single Tulips in twclve named sorts.

9 Double Tulips in three named sorts.

18 Narcissus, Paperwhite, early flowering.

36 Crocus in six named sorts.

Scilla Siberica, blue.

grow in soil, but do not

$D$ at $\$ 10.00$

24 Hyacinths in twenty-four named sorts for pots or glasses.

24 Hyacinths, early Roman, pure white.

12 Hyacinths, miniature, in four named sorts

48 Single Tulips in sixteen named sorts.

12 Double Tulips in four named sorts.

24 Narcissus, Paperwhite, early flowering

36 Single Narcissus in six named sorts.

12 Double Nareissus in four named sorts.

48 Crocus in eight named sorts.

12 Scilla Siberica, blue.

12 Blue Grape Hyacinths. $\}$ grow in soil, but do not

12 White Grape Hyacinths. $\}$ put in warm place. 


\section{HYACINTHS.}

It has always been admitted that Hyacinths-because of their large heads of fragrant flowers, held at uniform height on substantial stems-were ideal for the formal spring bulb bed.

But the flower lover who uses them only for this purposewho fails to thoroughly intersperse them in the front of the perennial and annual borders and beds, is losing sight of an opportunity to beautify such portions of his ground, at a season when bloom is otherwise sadly lacking.

Hyacinths are also one of the bets plants that can be relied upon to brighten the home during the months when nothing is in bloom outside. They force easily-if you tried them unsuccessfully it is probable that we may give you some hints which would obtain you better results. As a guide to best results we state below those that have given greatest satisfaction for forcing.

Plant six inches deep (to bottom of bulb) and six inches apart in beds.

\section{MIXED HYACINTHS.}

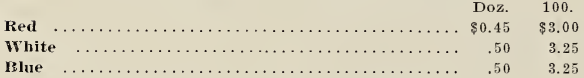

\section{BEDDING HYACINTHS.}

\section{Chiefly for Outside Planting.}

Although we reserve the right to ourselves to send out Bedding Hyacinths after our own Selection, yet we are willing to accommodate our customers as far as possible when they want us to send the Bedding Hyacinths with names attached.

This should be mentioned on the order sheet.

Single Rec

Rose and Pinl

White

Blue

Light and Porcelain Blue

Yellow

Double Red.

Rose

White

Blue

Light and Porcelain

Yellow

$\begin{array}{rc}\text { Doz. } & 100 \\ \$ 0.70 & \$ 4.50 \\ .60 & 4.00 \\ .70 & 4.50 \\ .75 & 5.00 \\ .75 & 5.00 \\ .80 & 5.50 \\ .80 & 5.50 \\ .80 & 5.50 \\ .80 & 5.50 \\ .85 & 6.00 \\ .85 & 6.00 \\ .85 & 6.00\end{array}$

\section{MINIATURE (Dutch Roman)} HYACINTHS.

These bulbs, if planted at the same time as Romans, or as soon as they are at hand, may be had in bloom in January, if grown inside. Grown outside they give fine results. By planting 8 to 10 inches deep the blooms last longer.

\section{SINGLE DARK RED.}

$1 \mathrm{my}$

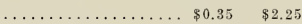

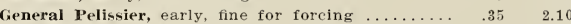

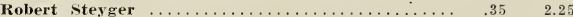

Roi

\section{SINGIE ROSE AND PINK.}

Baron van Thuyll, early $\ldots \ldots \ldots \ldots \ldots \ldots \ldots \ldots \ldots \quad .35 \quad 2.10$

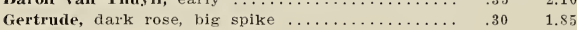

Giganthea, pale rose, big spike $\ldots \ldots \ldots \ldots \ldots \ldots \ldots, .35 \quad 2.25$

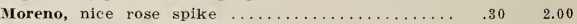

Rosea Maxima, nice spike $\ldots \ldots \ldots \ldots \ldots \ldots \ldots \ldots \ldots .30 \quad 1.75$

\section{SINGLE WHITE AND BLUSH.}

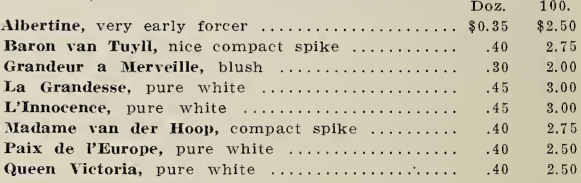

\section{SINGLE LIGHT BLUE.}

Czar Peter, very beautiful ................... $40 \quad 2.75$

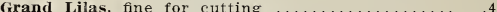

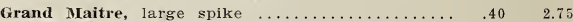

Johan, one of the best light blues ............ 40

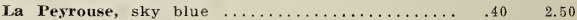

Regulus, big spikes ................... $40 \quad 2.50$

SINGLE DARK BLUE.

Baron van Tuyll, very early, dark ........... .45 3.00

King of the Blues, good spike .............. $45 \quad 3.00$

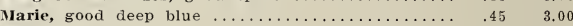

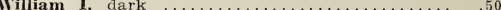

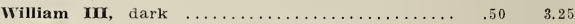

\section{SINGLE YELLOW.}

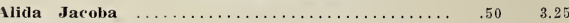

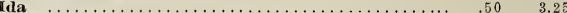

King of the Yellows, the best yellow ......... .50 3.50

MINIATURE HYACINTHS

(Dutch Roman). OUR SELECTION.

\begin{tabular}{|c|c|c|c|c|c|}
\hline ngle, & named & & red $\ldots \ldots \ldots \ldots \ldots$ & $\begin{array}{l}\text { Doz. } \\
\$ 0.30\end{array}$ & $\begin{array}{r}100 . \\
\$ 2.00\end{array}$ \\
\hline “. & " & .. & rose and pink ...... & .30 & 1.75 \\
\hline " & " & " & pure white $\ldots \ldots \ldots \ldots$ & .40 & 2.75 \\
\hline “ & “. & “ & creamy white and blush, & .30 & 2.00 \\
\hline . & * & .. & light and porcelain blue, & .40 & 2.50 \\
\hline " & “ & “ & dark blue $\ldots \ldots \ldots \ldots \ldots$ & .45 & 3.00 \\
\hline 4 & mixed & varieties, a & all colors $\ldots \ldots \ldots \ldots \ldots$ & .30 & 2.25 \\
\hline
\end{tabular}

\section{SECOND SIZED HYACINTHS FOR FORCING.}

Although as a rule first sized Hyacinths are superior to second sized ones when it comes to forcing, yet these $2 \mathrm{~d}$ sized Hyacinths will make a very nice display in beds or even when planted in pots. We feel convinced that you will be satisfied with them.

Six at a dozen price; 25 at hundred price.

\section{SINGLE DARK RED.}

Amy Doz. 100

. $\$ 1.00 \$ 7.00$

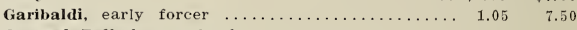

General Pelissier, early forcer ............ $1.05-\uparrow .50$

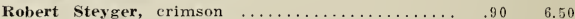

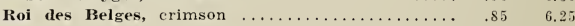

Bulbs so satisfactory are preparing another list.-Lockport, N. Y.

Our bulbs ordered from, you last year were so satisfactory that we have prepared a list for this fall. C. W. P., 5-20-13.

Bulbs very fine-oley, $\mathrm{Pa}$.

Received Bulbs-they are all very fine and I am well pleased. H. D., 11-4-12.

Every test order has proven our superiority. 


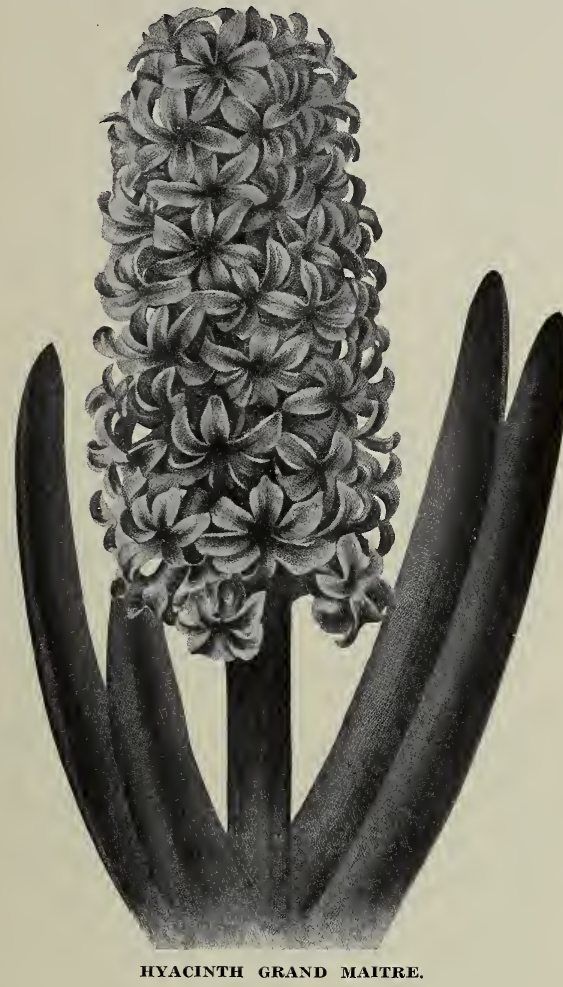

\section{SINGLE ROSE AND PINK.}

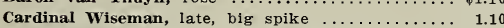
Charles Dickens, pink, very big spike ......... 1.15 Gertrude, dark rose, very nice .............. 80

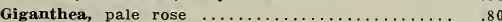
Grand Vainqueur, rose $\ldots \ldots \ldots \ldots \ldots \ldots \ldots \ldots \ldots, \quad 75$

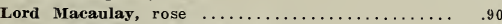
Maria Cornelia, pink, very early ........... 85 Yoreno, deep pink, big spike $\ldots \ldots \ldots \ldots \ldots \ldots \ldots \ldots \ldots$

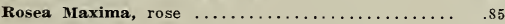

\section{SINGLE WHITE AND BLUSH.}

Albertine, elegant spike, early, pure white ........ Alba Superbissima, pure white .................... Baroness van Thuyll, pure white, compact spike.. 1.00 Blanchard, big spike, very early, pure white ..... .85 Grande Vedette, pure white ................ .80 Grandeur a Merveille, blush white, elegant spike.. $\quad .80$
Grande Blanche, compact spike, big bells ...... $.70 \quad 4.50$

La Franchise, creamy-white $\ldots \ldots \ldots \ldots \ldots \ldots \ldots \ldots \quad .75 \quad 5.00$

La Grandesse, finest pure white ............. $1.30 \quad 10.00$

L'Innocence, pure white, fine and early ........ $1.00 \quad 7.00$

Madame van der Yoop, compact spike, big bells.. $\quad .90 \quad 6.50$

\section{SINGLE LIGHT BLUE.}

Czar Peter, very beautiful, porcelain blue $\ldots \ldots \ldots, 1.25 \quad 9.50$

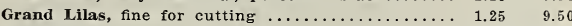

Johan, one of the best light blue $\ldots \ldots \ldots \ldots \ldots \ldots . .80 \quad 5.50$

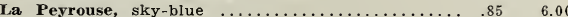

Lord Derby, very showy $\ldots \ldots \ldots \ldots \ldots \ldots \ldots \ldots \ldots, 1.25 \quad 9.50$

Queen of the Blues, fine spike $\ldots \ldots \ldots \ldots \ldots \ldots \ldots$

Regulus, big spike $\ldots \ldots \ldots \ldots \ldots \ldots \ldots \ldots \ldots \ldots \ldots, .90 \quad 6.50$

\section{SINGLE BLUE AND DARK BLUE.}

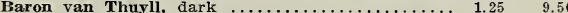

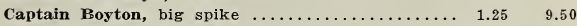

Grand Maitre, big spike, big bulb ........... 1.05 7.50

King of the Blues, dark, good spike ........... $1.25 \quad 9.50$

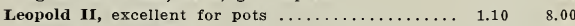

Marie, good deep blue .................... $1.05 \quad 7.50$

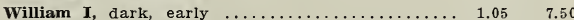

William III, dark, good spike .............. $1.10 \quad 8.00$

\section{SINGLE YELLOW.}

Alida Jacoba, pure yellow ................ $1.05 \quad 7.50$

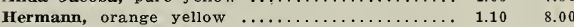

Ida, big spike, one of the finest yellows ........ $1.15 \quad 8.50$

King of the Yellows, extra big spike $\ldots \ldots \ldots \ldots \ldots, 1.10 \quad 8.00$

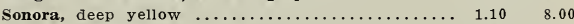

Vellow Hammer, golden yellow $\ldots \ldots \ldots \ldots \ldots \ldots . . .25 \quad 9.50$

\section{SINGLE MAUVE AND PURPLE.}

Haydn, blush violet $\ldots \ldots \ldots \ldots \ldots \ldots \ldots \ldots \ldots \ldots \ldots, 1.15 \quad 8.50$ Lord Balfour ........................ $1.00 \quad 7.00$

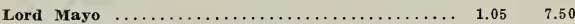
Sid Edwin Landseer, dark violet $\ldots \ldots \ldots \ldots \ldots \ldots \ldots, .90 \quad 6.50$ Sir William Mansfield, purple $\ldots \ldots \ldots \ldots \ldots \ldots \ldots . .90 \quad 6.50$

DOUBLE RED, LIGHT RED AND ROSE.

Bouquet Tendre, dark red $\ldots \ldots \ldots \ldots \ldots \ldots \ldots \ldots, 1.05 \quad 7.75$

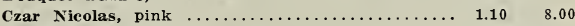

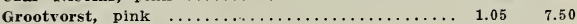

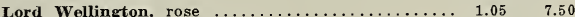

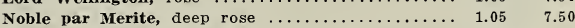

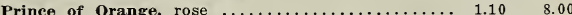

DOUBLE WHITE AND BLUSH WHITE.

Bouquet Royal, pure white $\ldots \ldots \ldots \ldots \ldots \ldots \ldots \ldots$ 1.05 7.50 Isabella, blush $\ldots \ldots \ldots \ldots \ldots \ldots \ldots \ldots \ldots \ldots \ldots \ldots, 1.05 \quad 7.50$

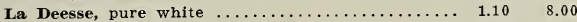

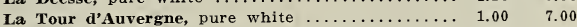

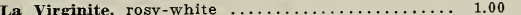

DOUBLE BLUE AND PORCELAIN BLUE.

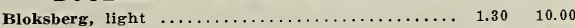
Charles Dickens $\ldots \ldots \ldots \ldots \ldots \ldots \ldots \ldots \ldots \ldots \ldots \ldots, 1.20 \quad 9.00$

Crown Prince of Sweden $\ldots \ldots \ldots \ldots \ldots \ldots \ldots \ldots \ldots \ldots 1.20 \quad 9.00$

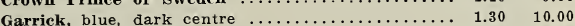

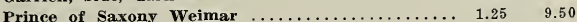

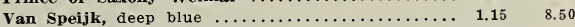

SINGLE BLUSH AND CREAMY WHITE.

*Grande Blanche, slightly blush ............ $1.15 \quad 8.50$ *Grandeur a Merveille, blush, big spike ......... $1.20 \quad 9.00$

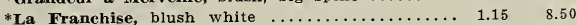

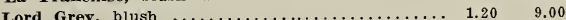

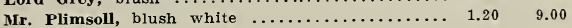

Very much pleased with bulbs.-Columbia, s. C.

The bulbs arrived last week in excellent condition. I am very much pleased with them. Miss F. H., 1-28-14. Very satisfactory.-Hillsdale, Mich.

The bulbs arrived in fine condition and are very satisfactory. M. W. D., 1-28-14.

"The result is our best testimonial." 


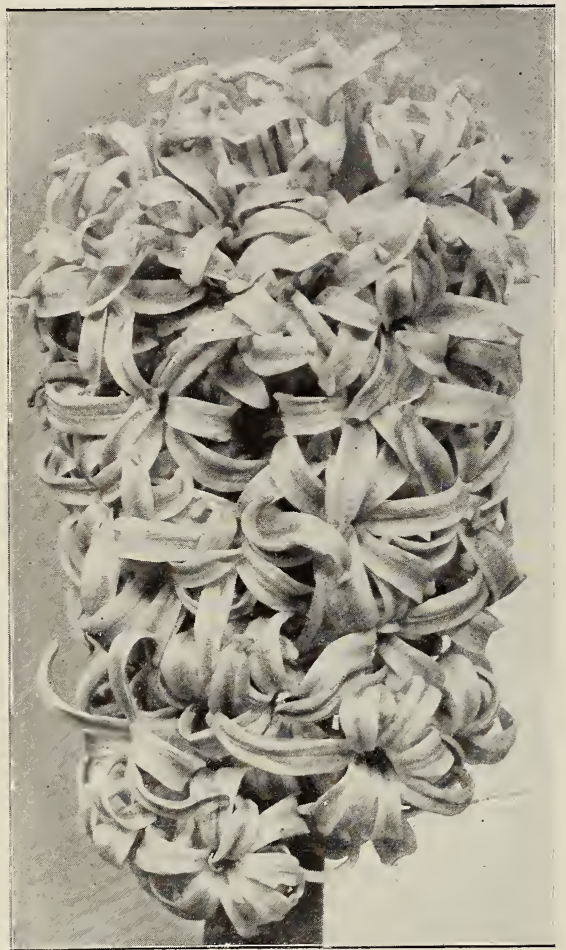

GERTRUDE (Dark Rose).

\section{NAMED HYACINTHS.}

First-sized Bulbs.

Six at dozen price; 25 at hundred price.

For bedding as well as forcing, it pays to buy first-sized Hyacinths of named varieties. Full spikes of true-to-name Hyacinths are well worth the investment.

You will note that as growers we. offer several times as many varieties as listed in most American catalogues, among them the best introductions in recent years.

The varieties marked with * are best for glasses or pots.

What W. K. call "Named Hyacinths first-sized Bulbs" are real first-sized Bulbs, and far superior to those often offered as first-sized Bulbs.

A slight difference in price, a big difference in quality.

Try our first size.

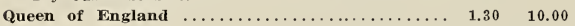

For Bedding purposes we give you the following combinations, which may be very handy for you.

Roi des Belges, dark red.

Mad. van der Hoop, white.

King of the Blues, dark blue.

King of the Yellows, golden yellow.

Gertrude, pink.

L'Innocence, pure white.

Roi des Belges, dark red.

King of the Yellows, yellow.

L'Innocence, pure white.

Johan, light blue.

Sir Wm. Mansfield, purple,

King of the Yellows, golden yellow.

\section{SINGLE RED.}

\begin{tabular}{|c|c|c|}
\hline Amy, c & $\begin{array}{l}\text { Doz. } \\
\$ 1.30\end{array}$ & $\begin{array}{c}100 . \\
\$ 10.00\end{array}$ \\
\hline Etna, half double, large bells ........ & 1.35 & 10.50 \\
\hline Fireball, deep orange-red $\ldots . .$. & 1.60 & 12.00 \\
\hline *Garibaldi, crimson, early forcer $\ldots \ldots \ldots \ldots \ldots \ldots$ & 1.25 & 9.50 \\
\hline * General Pelissier, dark red, forces very early .... & 1.20 & 9.00 \\
\hline${ }^{*}$ La Victoire, large crimson spike, early ...... & 1.60 & 12.00 \\
\hline Robert Steyger, fine for bedding $\ldots \ldots \ldots \ldots \ldots$ & 1.10 & 8.00 \\
\hline 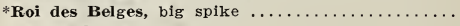 & 1.10 & 8.25 \\
\hline Vuurbaal & 1.40 & 11.00 \\
\hline
\end{tabular}

\section{SINGLE ROSE AND PINK.}

* Baron van Thuyll, pink ................. \$1.30 \$10.00

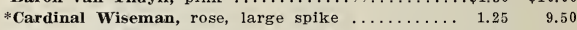

*Charles Dickens, pretty pink, nice flower ....... $1.30 \quad 10.00$

Fabiola, bright rose $\ldots \ldots \ldots \ldots \ldots \ldots \ldots \ldots \ldots \ldots .1 .25 \quad 9.50$

*Gertrude, dark rose, large truss ............ $.90 \quad 6.50$

* Gigantea, pale pink, gigantic truss .......... $1.00 \quad \mathbf{7 . 5 0}$

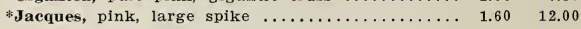

* Lady Derby, rose extra, new ................... $1.85 \quad 14.00$

*Lord Macaulay, pink, large spike ........... $1.10 \quad 8.00$

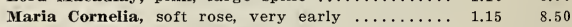

*Moreno, gigantic flower, deep rose ........... $1.15 \quad 8.50$

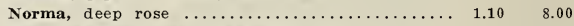

* Rosea Maxima, rose, large spike ............. $1.10 \quad 8.00$

* Rose a Merveille, deep pink, excellent spike ... $1.20 \quad 9.00$

Sultane favorite, bright rose, early .......... $1.20 \quad 9.00$

\section{SINGLE PURE WHITE.}

*Alba Maxima, very early $\ldots \ldots \ldots \ldots \ldots \ldots \ldots \ldots \ldots \$ \ldots \ldots \ldots \ldots \ldots$

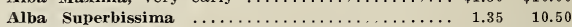

*Albertine, very early ................. $1.20 \quad 9.00$

Angenis Christina $\ldots \ldots \ldots \ldots \ldots \ldots \ldots \ldots \ldots \ldots, 1.30 \quad 10.00$

* Baroness van Thuyll, compact spike ........ $1.35 \quad 10.50$

Blanchard, very early, big spike .......... $1.25 \quad 9.50$

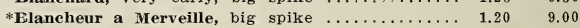

Grande Vedette $\ldots \ldots \ldots \ldots \ldots \ldots \ldots$

*La Grandesse, the best pure white .......... $1.85 \quad 14.00$

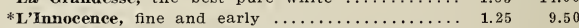

*Mad, van der Hoop, big bells, fine for bedding ... $1.20 \quad 9.00$

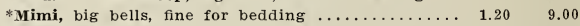

*Mina, early ....................... $1.25 \quad 9.50$

*Mont-Blane, nice spike ....................... $1.30 \quad 10.00$

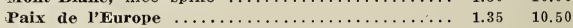

From Germantown, Pa.- "170 Balls on a single Hyacinth stalk!"

"The Tulips, Narcissus and Hyacinths which we had from you last fall have bloomed far better than any bulbs I have ever seen. Starting the week after Easter and ending last week, we have had continuous bloom. Were so fine that neighbors passing would stop frequently to admire the bulb beds. My sister next door secured bulbs from you at the same time and she also had remarkable success. The Hyacinthsall sent up two large flowers, witin the result that the bed was crowded, although the bulbs were planted well apart. One flower on the Gertrude Hyacinth was eleven inches in circumference, about $6 \frac{1}{2}$ inches high, and contained one hundred ard seventy bells. Have you ever heard of a bloom as large as this? C. B., 5-20-15. 


\section{SINGLE LIGHT BLUE.}

Bismarck, the earliest bight blue Hyacinth, very

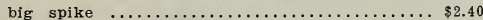
* Czar Peter, fine porcelain blue ............... 1.85 *Enchantress, nicely shaded, light blue ........ 1.85 *Grand Lilas, pale blue ..................... 1.50 Johan, light, good spike ................. 1.05

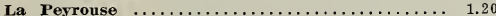

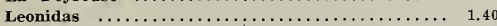

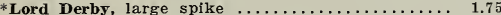

*Potgieter, very fine blue $\ldots \ldots \ldots \ldots \ldots \ldots \ldots \ldots \ldots, 1.60$

Princess Wilhelmina $\ldots \ldots \ldots \ldots \ldots \ldots \ldots \ldots \ldots \ldots, 1.85$

*Queen of the Blues, handsome big light blue spike 1.75

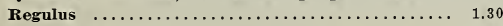

*Schotel, pale blue $\ldots \ldots \ldots \ldots \ldots \ldots \ldots \ldots \ldots \ldots \ldots, 1.60$

\section{SINGLE BLUE AND DARK BLUE.}

*Baron van Thuyll, dark ................... \$1.60

Bleu mourant, purplish blue $\ldots \ldots \ldots \ldots \ldots \ldots \ldots .1 .50$

*Captain Boyton, big spike like Gr. Maitre ..... 1.65

Charles Dickens, compact truss ............ 1.75

*Grand Maitre, big spike, big bulb ........... 1.25

King of the Blacks, the darkest blue, nearly black 2.00

*King of the Blues, dark, good spike......... 1.50

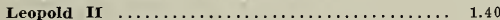

*Marie, good deep blue $\ldots \ldots \ldots \ldots \ldots \ldots \ldots \ldots . \ldots \ldots$

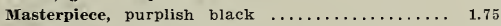

Uncle Tom, dark ........................ 1.85

William I, dark, early ................. 1.60

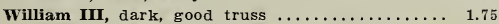

\section{SINGLE YELLOW AND ORANGE.}

Alida Jacoba, pure yellow .............. \$1.35

City of Haarlem, beautiful yellow ............ 2.40

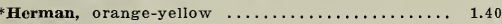

*Ida, big spike, one of the finest yellows ....... 1.50

*King of the Yellows, fine spike, specially recom-

mended $\ldots \ldots \ldots \ldots \ldots \ldots \ldots \ldots \ldots \ldots \ldots \ldots \ldots, 1.25$

La Citronniere, lemon-yellow ............. 1.30

La Pluie d'or, bright yellow $\ldots \ldots \ldots \ldots \ldots \ldots \ldots \ldots, 1.30$

L'or d'Australie, pure yellow ............. 1.25

Sonora, deep yellow ..................... 1.40

*Yellow Hammer, golden yellow .............. 1.50

\section{SINGLE MAUVE AND PURPLE.}

Haydn, blush violet $\ldots \ldots \ldots \ldots \ldots \ldots \ldots \ldots \ldots \ldots . \$ 1.40$

*Lord Balfour, mauve ................... 1.25

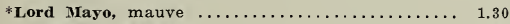

Sir Edwin Landseer $\ldots \ldots \ldots \ldots \ldots \ldots \ldots \ldots \ldots \ldots, 1.25$

* Sir William Mansfield, purple .............. 1.25

\section{DOUBLE HYACINTHS. DOUBLE RED, ROSE AND BLUSH.}

*Bouquet Tendre, well known, early variety, pink, $\$ 1.40$ Czar Nicholas, rosy blush ................ 1.50 Grootvorst, good spike ................ 1.60 Koh-i-Noor, semi-double, large truss .......... 1.50 Lord Wellington, large and magnificent spike ... 1.40 *Noble par Merite, large flower, rosy red, extra .. 1.50 Prince d'Orange, semi-double rose, splendid spike, $\mathbf{1 . 4 0}$

\section{DOUBLE WHITE.}

Bouquet Royal, pure white, fine spike $\ldots \ldots \ldots \ldots \$ 1.50$ Flevo, pure white $\ldots \ldots \ldots \ldots \ldots \ldots \ldots \ldots \ldots \ldots \ldots, 1.40$ *Isabella, large spike, extra .................. 1.35 La Deesse, pure white, early ............... 1.60 * La Grandesse, pure white, same bells as the single 1.60 *La Tour d'Auvergne, large spike, very early .... 1.35
La Virginite, blush

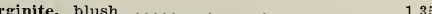

$1.40 \quad 11.00$

\section{DOUBLE BLUE}

$\$ 18.00$

14.00

14.00

11.50

7.50

9.00

11.00

13.00

12.00

14.00

13.00

10.00

12.00

\section{$\$ 12.00$}

11.50

12.50

13.00

9.50
15.00

15.00

12.50

11.00

10.50

13.00

14.00

12.00

13.00

\section{$\$ 10.50$}

18.00

11.00

11.50

9.50

10.00

10.00

9.50

11.00

11.50

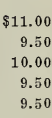

9.50
0.00

9.50

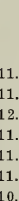

$\$ 11.50$

11.00

10.50

12.00

12.00

10.50

Albion, purplish blue, late $\ldots \ldots \ldots \ldots \ldots \ldots \ldots \ldots \ldots \$ 1.60 \quad \$ 12.00$

*Rloksberg, prettíly formed spike ........... $1.75 \quad \mathbf{1 3 . 0 0}$

Charles Dickens, good spike ................ $1.65 \quad 12.50$

Crownprince of Sweden, violet blue, large spike.. $\quad \mathbf{1 . 6 0} \quad \mathbf{1 2 . 0 0}$

Garrick, large spike, extra ................ $1.65 \quad 12.50$

*Lord Raglan, dark blue, light striped ......... $1.60 \quad 12.00$

Prince of Saxe-Weimar, semi-double, large spike, $1.60 \quad 12.00$

Rembrandt, large spike $\ldots \ldots \ldots \ldots \ldots \ldots \ldots \ldots \ldots, 1.75 \quad 13.00$

*Van Speijk, large spike and bells ............ $1.50 \quad 11.50$

\section{DOUBLE YELLOW AND ORANGE.}

Bouquet Orange, good flower $\ldots \ldots \ldots \ldots \ldots \ldots \ldots \ldots 1.50 \quad \$ 11.50$ *Goethe, very fine spike, splendid spike $\ldots \ldots \ldots \ldots . \ldots 1.60 \quad 12.00$ *Jaune Supreme, yellow with rose centre $\ldots \ldots \ldots .1 .40 \quad 11.00$ Sovereign, good truss $\ldots \ldots \ldots \ldots \ldots \ldots \ldots \ldots \ldots \ldots .1 .75 \quad \mathbf{1 3 . 0 0}$

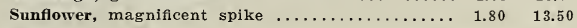
William III, large ...................... 1.5v 11.50

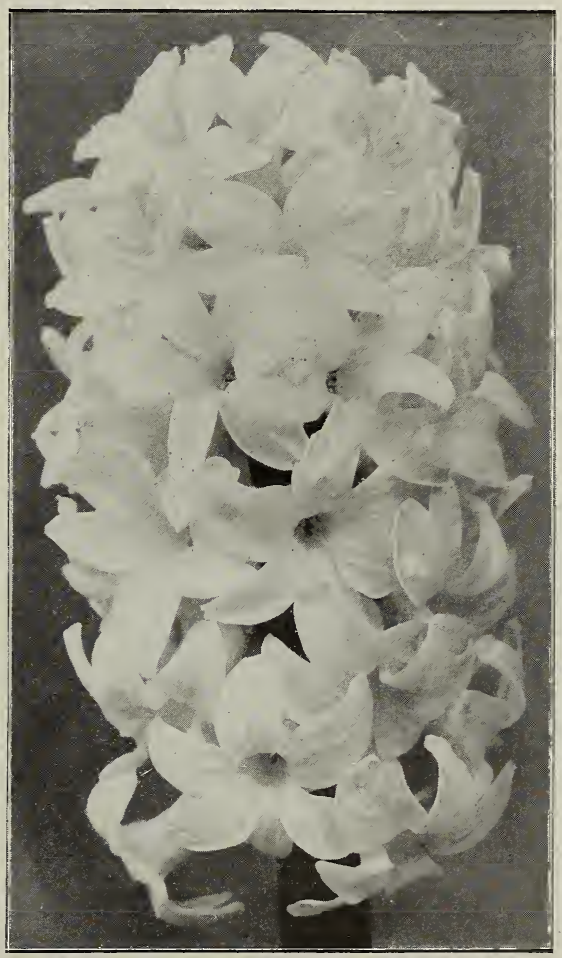

L'INNOCENCE (Pure White).

From Overbrook, Pa.- "More than two large Hyacintlis to each bulb."

"Last fall I purchased ten dozen Hyacinths from your firm for my garden. I am pleased to say that they made the finest display this spring that I have ever seen, and I have grown Hyacinths for over thirty years. They averaged more than two very large blooms to each bulb. The Darwin Tulips won praises from all who saw them-the colors were magnificent and the blooms unusually lasting." J. L. A., 5-10-15. 


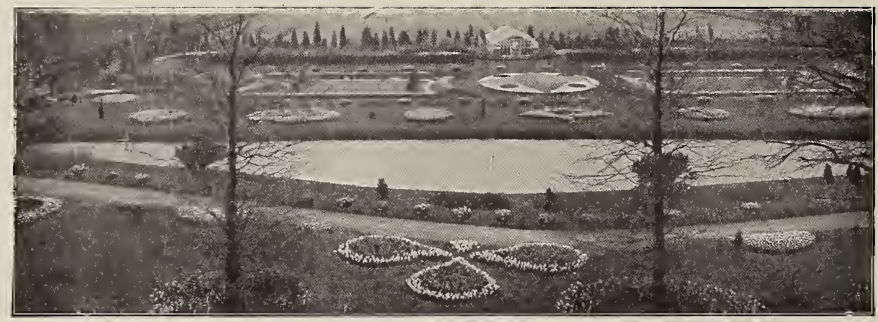

\section{The Coming Tulips}

History tells us that the culture of Tulips was started in Holland in the year 1571 . From 1634 until 1637 the famous "Tulpomania" reigned, during which time ridiculous high prices were paid for one bulb.

Every year new specialties are grown by Holland growers, but in nearly all cases they are retained in that country until the growth is larger and they can supply the entire market.

The policy of our house is different-we believe the bulb-lover of America is entitled to these varieties, and we offer them after thorough tests for your approval.

\section{SINGLE VARIETIES}

Calipso. Like Herman Schlegel, but far bigger; resembles the White Hawk in

habit $\ldots \ldots \ldots \ldots \ldots \ldots \ldots \ldots \ldots \ldots \ldots . \$ 20 \quad \$ 2.20 \quad \$ 18.00$

Casuaris. This flower has an excellent form, it resembles the La Reine Maximus, but is deeper rose colored $\ldots \ldots \ldots \ldots \ldots \ldots$

Colibri. The color is lighter yellow than Herman Schlegel; it is yellow all over. It is of a nice, round form and certainly one of the beauties in Early-Tulips ....

Columba. This sort is rosy-pink, well formed, short, broad flower .........

Crimson Queen. The color is dark crimson with a mauve shade in it; forces easily

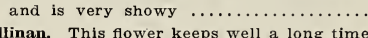
has an excellent form and its color is of finest deep rose $\ldots \ldots \ldots \ldots \ldots \ldots \ldots$

Goud Elsje. This sort has a peculiar color the under half part is yellow, while the upper part is white, suffused with light

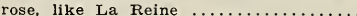

Herman Schlegel. The yellow La Reine. This flower is of a light yellow color and has the same light rose like the $\mathrm{La}$ Reine; it is an easy forcer

\section{Ea. Doz, 100}

$\begin{array}{lll}.30 & 3.20 & 25.00\end{array}$

$.50 \quad 5.50$

$1.00 \quad 11.00$

$1.00 \quad 11.00$

$15 \quad 1.65 \quad 13.50$

$20 \quad 2.20 \quad 18.00$

$.05 \quad .35 \quad 2.00$
Ibis. This sort is of a peculiar color; well, we should say it is after the red cabbage, the outside petals are running into rose, the flower is very big and forces very easily ............. \$2.00

La Reine des Reines. (Prosperity) Delicate and lovely pink, very early, splendid

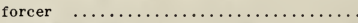

La Reine Maximus. An improvement of the well-known La Reine, far bigger .....

La Reine Victoria. The pure white La Reine, with all the good capacities of that sort, besides the stems are stronger

Pelican. Large white flower lightly suffused with rose on upper petals; one of the biggest flowers $\ldots \ldots \ldots \ldots \ldots \ldots \ldots$

Prinses Juliana. The color is of the finest

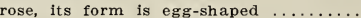

Red Hawk. A robust flower; the color is somewhat like Prince of Austria, but outside petals are slightly colored yellow

Rose Hawk. The same robust habit as White Hawk, but light rose colored all

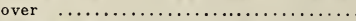

Rose La Reine. Something after Prosperity, darker pink and smaller flower ........

Striped Hawk. The same robust habit as White Hawk, but the color is a peculiar

combination of red and rose $\ldots \ldots \ldots 2.00$
Ta. 100

$.08 \quad .75 \quad 5.00$

$15 \quad 1.70 \quad 13.50$

$.35 \quad 3.75$

$1.25 \quad 13.75$

$.15 \quad 1.65 \quad 13.50$

$\begin{array}{lll}.15 & 1.65 \quad 13.5\end{array}$

$.07 \quad .60 \quad 3.90$

\section{DOUBLE VARIETIES}

Apple Blossom. The color is like the Peach Blossom and even finer, but the tulip is

not so double as that sort $\ldots \ldots \ldots \ldots . \$ 2.00 \$ 22.00$

Boule de Neige. Also a pure white sport of Murillo, which forces easily, the whole when in flower is something after a white Pæony $\ldots \ldots \ldots \ldots \ldots \ldots \ldots \ldots \ldots$

Electra. The color is like that of the crimson Queen, the shape is just as that of the Murillo and is has the good capacities of that well-known sort in every

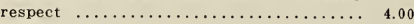

\section{Doz. 100 .}

Mary Garden. Pure yellow, the shape of Murillo, the only pure yellow double

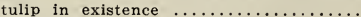

Peach Blossom. Excellent dark silky rose, the finest double rose Tulip known ....

Schoonoord. A pure white Sport of Murillo, with all the good qualities of that wellvariety. Excellent forcer .............

Theeroos (Tea rose). Another Sport of Murillo, called Theeroos (tea rose) because it is both in color and shape like that

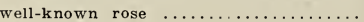

Ea. Doz. 100.

$.50 \quad 5.50$

From Philadelphia, Pa._-"Blooms of exceptional color and texture."

"The flowers from the last bulbs bought in the fall were superb. Blooms were of exceptional color and texture and I will be glad to order again." H. J., 5-11-15. 


\section{TULIPS} beds.

Plant 4 inches deep (to top of bulb) and 4 inches apart in

The culture of Tulips is one of our great specialties. Being owners of the very best grounds for Tulips ( rich loam and pure sand), we dare say our Tulips are unsurpassed and sure to give the greatest satisfaction, for forcing as well as for bedding purposes.

\section{ARRANGEMENTS OF COLORS FOR BEDDING.}

Chrysolora and Dusart, or Artus or Belle Alliance.

Couleur Cardinal, bedded by itself, makes one of the most beautiful beds.

Cottage Maid and Yellow Prince.

Duc De Berlin and White Hawk.

Duchesse de Parma, all by itself.

Keizerskroon, all by itself.

La Reine and Artus.

Maes, unsurpassed when bedded without anything else.

Pottebakker White and Chrysolora.

Princess Marianne and Ophir d'Or.

Prince of Austria and Herman Schlegel.

President Lincoln, all by itself.

Rose Gris de Lin, separate in one bed.

Thomas Moore, all by itself.

Van der Neer and Ophir d'Or.

Vermillion Brilliant and White Hawk.

\section{SORTS RECOMMENDED FOR FORCING.}

A very handy way to force Tulips is the following:

Make a little box say $18^{\prime \prime} \times 9^{\prime \prime} \times 5^{\prime \prime}$, putting the boards at the bottom one-quarter of an inch apart for drainage. Fill the box three-quarters with good soil and place the Tulips in, covering them up. They may be placed almost touching each other. Put the box in the ground and cover deep with ashes or soil or manure. After some eight weeks when the bulbs have sufficient roots, dig the boxes up and place in light and heat, keeping them well moist. When the bulbs are in flower, dig them up very carefully and place in fancy basket or pot filled with damp moss or earth. They are then very even and will last as long as if forced in the pots.

For forcing the following varieties are highly desirable.
If you will note these suggested varieties you may have a complete succession of bloom from Christmas until the Easter season.

\section{For Flowering in December and Early January.}

THE DUC VON THOL VARIETIES, MON TRESOR, PROSERPINE, THOMAS MOORE, VERMILION BRILLIANT and WHITE POTTEBAKKER.

\section{For Flowering January until March.}

BELLE ALLIANCE, DUCHESSE de PARMA, KEIZERSKROON, LA REINE, PRINCE OF AUSTRIA, ROSE GRIS DE LIN, VERMILION BRILLIANT, YELLOW PRINCE.

For Flowering from Early March to Early April.

BELLE ALLIANCE, COULEUR CARDINAL, FLAMINGO, LA REINE, PRINCE DE LIGNY, PRINCE OF AUSTRIA, PROSPERITY, ROSE GRIS DE LIN, ROSE LUISANTE, VER MILION BRILLIANT, WHITE HAWK, YELLOW PRINCE.

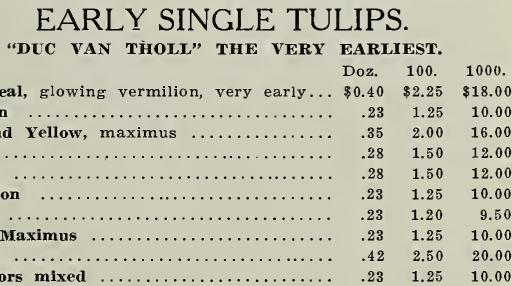

The varieties marked 1 generally begin to flower about the 20 th of April, those marked 2 after the first of May.

By selecting bulbs preceded by the same figure, and of the colors desired, you find the problem of making up a bed of Tulips, pleasing in color combination, which will bloom at about the same time, very much simplified.

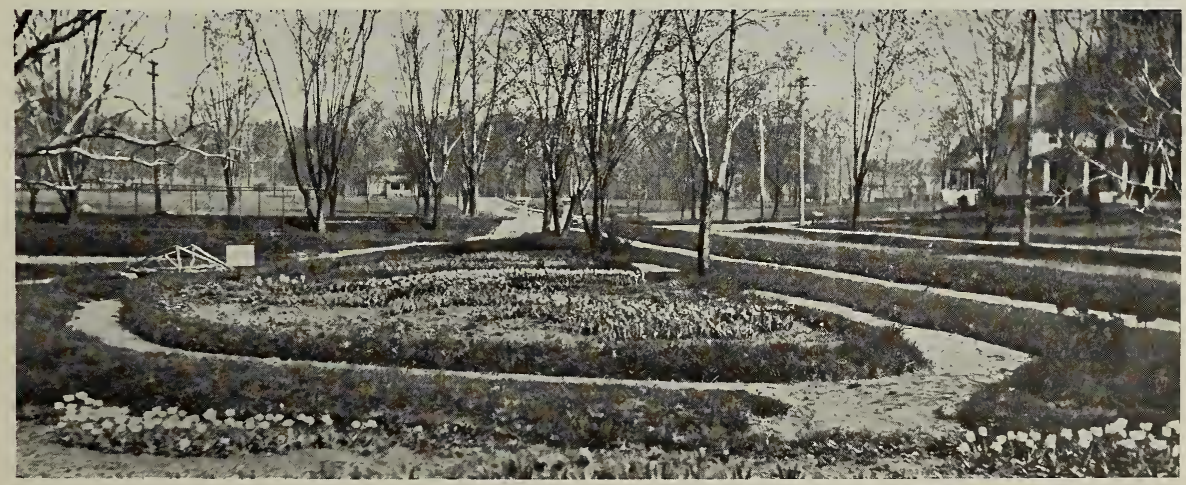

From Beverly, Mass.- "Superior to the blooms in the Boston Public Garden.'

"The Tulips were fine. My 'Duchess de Parma,' 'Maes,' and 'Rose Gris de Lin' were equal, if not superior to the blooms in the Boston Public Garden. My mixed bed also was very good." P. A. T., 5-9-13.

From Nelsonville, N. J.- "Don't see how they could be finer."

"Holland Bulbs received in fine shape. I don't see how they could be better." Mrs. E. N. N., 11-2-14. 


\section{EARLY SINGLE TULIPS-Continued. Doz. $\quad 100 . \quad 1000$.} MIXED EARLY SINGLE TULIPS ........ $\$ 0.15 \quad \$ 0.85 \quad \$ 7.25$

1-Adeline, rosy violet, with a yellow centre.

Height 8 inches $\ldots \ldots \ldots \ldots \ldots \ldots \ldots \ldots, \$ 0.43 \quad \$ 2.45 \quad \$ 19.60$

2-Alba Regalis, white, faintly edged pale yellow. Height 10 inches ........... .30 $1.65 \quad 13.20$

$\begin{array}{lllll}\text { Arms of Leiden, white flamed carmine.. } & .23 & 1.25 & 10.00\end{array}$

2-Artus, rich scarlet, with clear yellow centre. Height 10 inches ...........

1-Belle Alliance (Waterloo), crimson-scarlet, with yellow centre. Height ? inches $\ldots \ldots \ldots \ldots \ldots \ldots \ldots \ldots \ldots \ldots$.

Berchem, brilliant clear carmine ......

1-Bride of Haarlem, carmine, feathered white. Height 8 inches .............

1-Brilliant Star, brilliant scarlet, color and habit as Vermilion Brilliant, but much larger, splendid early forcer .........

2-Brutus, orange scarlet, edged yellow. Height 8 inches $\ldots \ldots \ldots \ldots \ldots \ldots \ldots$.

1-Canary Bird, rich yellow. Height 11 ins. $\quad .28 \quad 1.55 \quad 12.40$

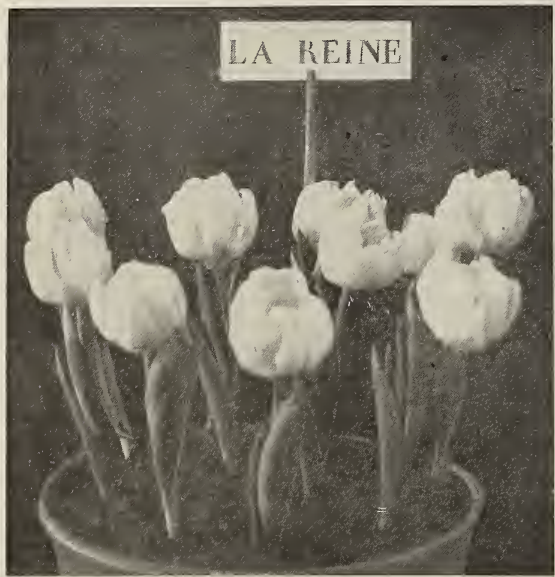

2-Cerise Gris de Lin, rosy-violet. Height

10 inches $\ldots \ldots \ldots \ldots \ldots \ldots \ldots \ldots \ldots \ldots \ldots$ \$0.80 $\$ 4.75 \quad \$ 38.00$

1-Chrysolora, deep golden-yellow. Height

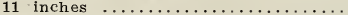

1-Claremont Gold, orange-scarlet. Height 12 inches $\ldots \ldots \ldots \ldots \ldots \ldots \ldots \ldots \ldots \ldots$

1-Claremont Silver, carmine and white. Height 12 inches $\ldots \ldots \ldots \ldots \ldots \ldots \ldots$

1-Claremont White, white. Height 12 inches $\ldots \ldots \ldots \ldots \ldots \ldots \ldots \ldots \ldots \ldots \ldots \ldots$.

1-Cottage Boy, orange-red bordered orangeyellow. Height 9 inches $\ldots \ldots \ldots \ldots$.

1-Cottage Maid, lovely rosy pink shading to cream-white. Height 9 inches $\ldots .$.

2-Couleur Cardinal, intense crimson, sha-
ded with plum on the exterior, yellow

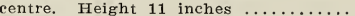

A grand Tulip, which makes a very decided show in a bed.
2-Couleur Ponceau, cerise, flushed white. Height 1 foot.$\ldots \ldots \ldots \ldots \ldots \ldots \ldots$

1-Crimson King, crimson. Height 12 ins.

1-Due de Berlin, scarlet, edged orangeyellow. Height 8 inches ............

2-Duchess of Parma, large orange-red with a bold irregular margin of deep yellow, suffused with rose on the outer petals. Height 13 inches ...........

2-Dusart, crimson-scarlet, with greenish yellow centre. Height 10 inches .....

2-Flamingo, shape like White Hawk, color white, flaked rosy red $\ldots \ldots \ldots \ldots \ldots$

A variety which has not been on the market very long. In forcing it gives great satisfaction, the color resembling the beautiful plumage of the flamingo bird.

1-Fred. Moore, bright orange shaded with scarlet, handsome and effective. Height

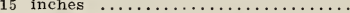

Very sweet-scented and of a fashionable color.

2-Goldfinch, the pure yellow golden Prince

1-Grace Darling, large dull orange-scarlet, with dark blue centre. Height 12 ins.

1-Joost van den Vondel, rosy red, more less flaked with white, and suffused with delicate rose on the outside. Height 10 inches $\ldots \ldots \ldots \ldots \ldots \ldots \ldots$.

1-Joost van den Vondel, white, pure white extremely beautiful. Height 10 inches,

Kardinalshat, brown bordered orange

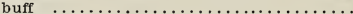

1-Keizerkroon (Grand Duc), crimson-scarlet, edged bright yellow. Height 14

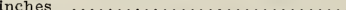

Owing to its enormous cup and broad foliage this variety is generally looke upon as one of the best for outdoor work. The striking contrast of the yeland red in the flower makes it very showy.

1-King of the Yellows, pure yellow in the way of Canary Bird, but far superior. Height 12 inches $\ldots \ldots \ldots \ldots \ldots \ldots \ldots$

2-Koh-i-noor, very dark rich scarlet. Height $7-9$ inches $\ldots \ldots \ldots \ldots \ldots \ldots \ldots$

La Precieuse (vide Cottage Maid).......

1-Ca Reine (Queen Victoria), white suf fused with delicate pink. Height 1

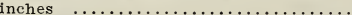

1-La Remarquable, dark purple. Height 10 inches $\ldots \ldots \ldots \ldots \ldots \ldots \ldots \ldots \ldots \ldots \ldots \ldots$

$30 \quad 1.7514 .00 \quad 1$-Ce Matelas, silvery pink, tipped with white and shaded with blush white, early and very effective. Height $1 \mathrm{ft}$,

2-L'Immaculee, pure white. Height 8 ins.

1-Maes, rich scarlet, tinged with purple on the interior, centre bronze surrounded with bright yellow; the finest tulip for bedding. Height 10 inches ..........

1-Mon Tresor, intense golden yellow. Height 11 inches $\ldots \ldots \ldots \ldots \ldots \ldots \ldots$.

Is very easy to force, one of the varietie you should start your experiments with because you will be certain of good results if you follow our instructions.

2-Nelly (Grande Blanche), pure white. Height 9 inches $\ldots \ldots \ldots \ldots \ldots \ldots \ldots . . . \ldots$
Doz. 100.1000.

$.23 \quad 1.25 \quad 10.00$

$.23 \quad 1.25 \quad 10.00$

$.30 \quad 1.75 \quad 14.00$

$24 \quad 1.30 \quad 10.40$

$27 \quad 1.45 \quad 11.50$

$.80 \quad 4.65 \quad 37.20$

$.27 \quad 1.45 \quad 11.50$

$\begin{array}{lll}.62 & 3.50 \quad 28.00\end{array}$

$\begin{array}{lll}37 & 2.15 & 17.20\end{array}$

$62 \quad 3.50 \quad 28.00$

$.23 \quad 1.25 \quad 10.00$

$42 \quad 2.50 \quad 21.00$

$.30 \quad 1.65 \quad 1320$

$\begin{array}{lll}70 & 4.00 \quad 32.00\end{array}$

$\begin{array}{lll}.23 & 1.25 & 10.00\end{array}$

$\begin{array}{lll}.18 & 1.00 \quad 8.00\end{array}$

$.80 \quad 4.75 \quad 38.00$

$\begin{array}{lll}50 & 2.95 & 23.60\end{array}$

$21 \quad 1.15 \quad 9.20$

$\begin{array}{lll}.47 & 2.75 & 22.00\end{array}$

$\begin{array}{lll}.40 & 2.25 & 18.00\end{array}$

$.23 \quad 1.25 \quad 10.00$

From St. Paul, Minn._-Firmest I ever handled-could have sold all at an advance."

"Bulbs reached me in good condition. Everyone satisfied. Words fail me in expressing my thanks and appreciation, especially for the extras, as they certainly were unexpected. I have planted about 200 to date and $I$ am more than pleased with the bulbs, as they are the firmest and best looking bulbs I have ever handled. I hope to place an order for Gladiolus soon. Could have sold all my bulbs and a lot more at a nice advance, but I did not buy to sell." M. E. G., $10-30-14$. 
1-Ophir d'Or, canary yeliow, very sweet scented. Height 11 inches. The very

best single yellow tulip for bedding.. $\$ 0.30 \quad \$ 1.65 \quad \$ 13.20$

2-Pink Beauty, bright rose pink, shading to blush white near the yellowish centre. Height 11 inches. Award of merit R. H. S., May 8 th, $1900 \ldots \ldots$.

1-Pottebakker, pure yellow. Height 13

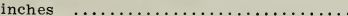

2-Pottebakker, scarlet (Verboom), rich scarlet with a yellow centre. Height

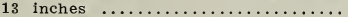

1-Pottebakker, white, large cup-shaped pure white flowers. Height 13 inches.

2-Potter, rich purple. Height 10 inches..

1-President Lincoln (Queen of the Violets) rose-purple, edged with white. Height 8 inches $\ldots \ldots \ldots \ldots \ldots \ldots \ldots \ldots \ldots \ldots \ldots \ldots$

1-Prince de Ligny, golden yellow. Height

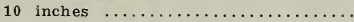

2-Prince of Austria, scarlet suffused with orange, yellow centre, sweet scented. Height 12 inches $\ldots \ldots \ldots \ldots \ldots \ldots \ldots$.

1-Princess Marianne, creamy-white, suf fused with pink, shading to rose; very large. Height 10 inches ............

1-Proserpine, bright rose, suffused with purple, very handsome. Height 12 inches $\ldots \ldots \ldots \ldots \ldots \ldots \ldots \ldots \ldots \ldots$.

Also a very easy forcing variety.

1-Queen of the Netherlands, large globeshaped tulip of softest rosy white. Height 13 inches $\ldots \ldots \ldots \ldots \ldots \ldots \ldots$

1-Queen of the Violets (President Lincoln),

Rachel Ruysch, cherry color ..........

1-Rembrandt, large glowing crimson.

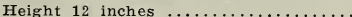

2-Kosamundi Huyckman, white tipped rose and suffused rose pink. Height 10

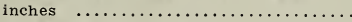

Rose Aplatie, soft rose $\ldots \ldots \ldots \ldots \ldots \ldots$

2-Rose Gris de Lin, rose flushed with pink axpllent shape. Height 8 inches ...

A most beautiful and useful variety which should be included in every order.

2-Rose Luisante, dark silky rose, the finest rose tulip. Height 9 inches .........

1-Sir Thomas Lipton, rich crimson-scarlet,

Standard Golden, scarlet, tipped and flaked with yellow. Height 10 inches.

2-Standard Royal (Silver Standard), white ground, flaked and tipped with scarlet.

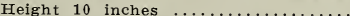

2-Thomas Moore, bright orange, shaded with scarlet; very handsome and effective. Height 14 inches ..............

1-Van der Neer, large violet purple. Height 10 inches $\ldots \ldots \ldots \ldots \ldots \ldots \ldots \ldots \ldots \ldots \ldots$

2-Van Gooijen, fine rose. Height 9 inches,

Verboom, rich scarlet, yellow centre.

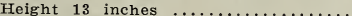

1-Vermilion Brilliant, dazzling scarlet, with yellow centre. Height 10 inches,

This variety is considered by a good many as the best scarlet. It certainly deserves all the credit which is given to it.

1-Vesuvius, deep scarlet. Height 10 inches,

1-White Hawk, pure white, robust habit; one of the very best white Tulips.
Doz. 100.1000.

$2.25 \quad 18.00$$$
.40
$$

$\begin{array}{lll}75 & 4.25 & 34.00\end{array}$

$.75 \quad 4.25 \quad 34.00$

$.23 \quad 1.25 \quad 10.00$

$.30 \quad 1.65 \quad 13.20$

$.22 \quad 1.15 \quad 9.20$

$3.50 \quad 28.00$

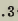

$1.75 \quad 14.00$

$\begin{array}{lll}72 & 4.25 & 34.00\end{array}$

$.25 \quad 1.35 \quad 10.75$

$47 \quad 2.75 \quad 22.00$

$\begin{array}{lll}.22 & 1.15 & 9.20\end{array}$

$\begin{array}{lll}.48 & 2.85 & 22.80\end{array}$

$.20 \quad 1.10 \quad 8.75$

$\begin{array}{lll}.55 & 3.25 & 26.00\end{array}$

$\begin{array}{lll}.75 & 4.50 & 36.00\end{array}$

4.50

36.00

$\begin{array}{lll}.23 & 1.25 \quad 10.00\end{array}$

$\begin{array}{lll}1.00 & 6.00 & 47.50\end{array}$

$\begin{array}{rrr}.30 & 1.75 & 14.00\end{array}$

$\begin{array}{lll}.38 & 2.15 & 17.20\end{array}$

$\begin{array}{lll}.38 & 2.15 & 17.20\end{array}$

$.47 \quad 2.75 \quad 22.00$ $\begin{array}{lll}.40 & 2.20 & 17.60\end{array}$
Height 12 inches. (Fine white for Doz. 100.1000.

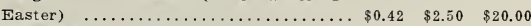

This flower is one of the largest, and

will add wonderfully to your garden.

2-White Swan, true, pure white, eggshaped flowers. Height 14 inches ....

This variety cannot be forced, but for outdoor planting it is very useful. Its name indicates its shape. The flowers are borne on long Swan-necked-shaped stems, which give it a very graceful appearance.

1-Wouwerman, rich dark purple. Height 10 inches ..................... $75 \quad 4.50 \quad 36.00$

2-Xellow Prince, rich yellow, sweet-scented. Height 9 inches $\ldots \ldots \ldots \ldots \ldots \ldots \ldots \ldots . .25 \quad 1.35 \quad 10.80$ Yellow Queen, deep yellow, extra $\ldots \ldots \ldots \quad .47 \quad 2.75 \quad 22.00$

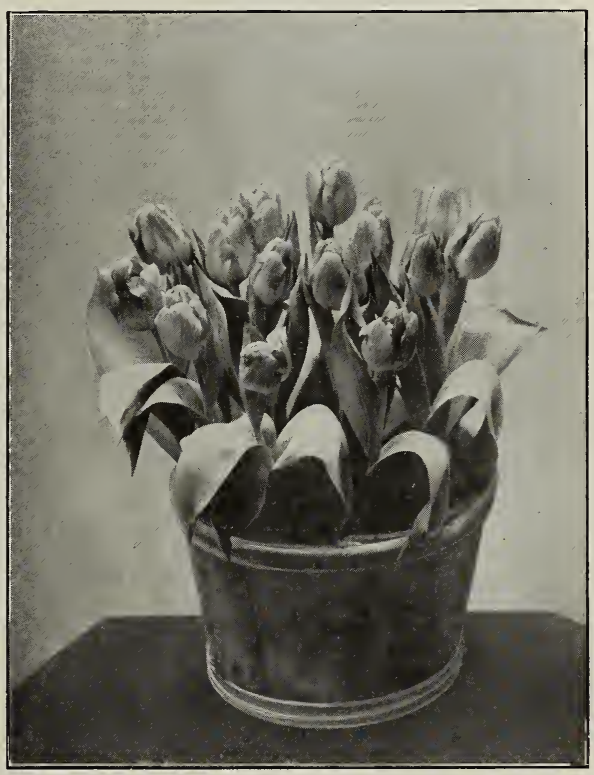

EARLY DOUBLE TULIPS.

The varieties marked 1 generally begin to flower last week of April; those marked 2 first week in May, while the latest to flower are marked 3 .

\section{ARRANGEMENTS FOR PLANTING DOUBLE TULIPS IN BEDS.}

Double tulips should be placed one variety in each bed; grouping different varieties does not produce such a good effect. We advise for that purpose the following splendid varieties: COURONNE D'OR, LA CANDEUR, LADY PALMERSTON, LE MATADOR, MURILLO, SALVATOR ROSE, WILLIAM III and LA CANDEUR, all by itself.

From Angels Camp, Cal.- "I only regret that I did not order more."

"I am pleased to write that I received the tulip bulbs ordered from you and I never saw better bulbs-expect a gorgeous bed of them next spring. I only regret that I did not order some hyacinths at the same time. Thanks for such fine, healthy bulbs-have shown them and recommended them to my friends." Mrs. K. C. C. 


\section{DOUBLE TULIPS SUITABLE FOR FORCING.}

\section{For Flowering in January. SALVATOR ROSA.}

\section{For Flowering End of January to End of March.}

COCHENILLE, COURONNE D'OR, EL TOREADOR, IMPERATOR RUBRORUM, MURILLO, TITIAN, TOURNESOL; YELLOW TUORNESOL.

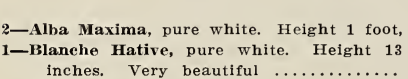
inches. Very beautiful $\ldots \ldots \ldots \ldots \ldots \ldots \ldots$.

1-Couronne des Roses, rich pure rose, shaded white. Height 11 inches. Extra.

1-Couronne d'Or, deep yellow, marked with orange red. Height 11 inches ........

Crown of Gold would be the English name for this variety, and it certainly is a golden Crown when in flower. It makes a splendid bedding Tulip.

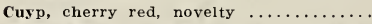

2-El Toreador, reddish bronze and orange with a yellow base; very handsome. Height 11 inches. Award of Merit R. H. S., May 9 th, $1900 \ldots \ldots \ldots \ldots \ldots$

1-Fluweelen Mantel (Velvet Gem), deep crimson, edged dark orange-yellow. Height 10 inciles $\ldots \ldots \ldots \ldots \ldots \ldots \ldots$

1-Gloria Solis, rich yellow, running to deep red. Height 12 inches $\ldots \ldots \ldots \ldots \ldots$

Graaf van Leicester, yellow edged orange,

Helianthus, red, yellow bordered; large flowers.$\ldots \ldots \ldots \ldots \ldots \ldots \ldots \ldots \ldots \ldots \ldots$

2-Imperator Rubrorum, bright scarlet.

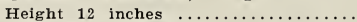

2-La Candeur, pure white. Height 11 inches. Remains in flower a very long time $\ldots \ldots \ldots \ldots \ldots \ldots \ldots \ldots \ldots \ldots \ldots$

1-Lady Palmerston, deep rose, shaded with white at base. Height 10 inches .....

2-La Grandesse, soft rose, shaded white.

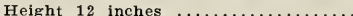

1-Le Matador, scarlet with purple glow at the outside of the petal. Height 12 inches. Extremely beautiful .........

2-Le Blason, blush pink. Height 11 inches Leo XII, light red $\ldots \ldots \ldots \ldots \ldots \ldots \ldots$.

2-Lord Beaconsfield, brilliant crimson rose, the shape of the flower resembles a giant Ranunculus. Height 10 inches. .

2-Murillo, delicate blush pink. Height 10

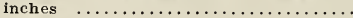

Most decidedly one of the best double Tulips known. It is very fine for foreing purposes as well as for outside work.

Parmesiano, rosy red; splendid ........

1-Prineess Alexandra, scarlet and yellow. Height 10 inches $\ldots \ldots \ldots \ldots \ldots \ldots \ldots$

3-Queen of the Netherlands, white flushed rose. Height 10 inches .............

1-Raphael, pink shaded rose; extra. Height 9 inches $\ldots \ldots \ldots \ldots \ldots \ldots \ldots \ldots \ldots \ldots \ldots$.

2-Rex Rubrorum, bright scarlet. Height

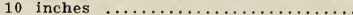

2-Rose blanche, snow-white, excellent bedding tulip. Height 8 inches ......... $\begin{array}{lll}42 & 2.50 & 20.00\end{array}$

$\begin{array}{lll}.40 & 2.35 & 18.80\end{array}$

$.55 \quad 3.25 \quad 26.00$

$.42 \quad 2.50 \quad 20.00$

$\begin{array}{lll}62 & 3.50 \quad 28.00\end{array}$

$.75 \quad 4.50 \quad 36.00$

$.40 \quad 2.25 \quad 18.00$

$\begin{array}{lll}.32 & 1.85 & 14.80\end{array}$

$\begin{array}{lll}.42 & 2.50 \quad 20.00\end{array}$

$.40 \quad 2.25 \quad 18.00$

$40 \quad 2.25 \quad 18.00$

$.23 \quad 1.25 \quad 10.00$

$40 \quad 2.25 \quad 18.00$

$40 \quad 2.35 \quad 18.80$

$\begin{array}{lll}.42 & 2.45 & 19.60\end{array}$

$\begin{array}{lll}.42 & 2.45 & 19.60\end{array}$

$.42 \quad 2.45 \quad 19.60$

$.42 \quad 2.45 \quad 19.60$

$.22 \quad 1.15 \quad 9.20$

$\begin{array}{lll}.42 & 2.50 \quad 20.00\end{array}$

$.40 \quad 2.25 \quad 18.00$

$.70 \quad 4.00 \quad 32.00$

62
$.5 .50 \quad 28.00$

$\begin{array}{lll}.32 & 1.85 & 14.80\end{array}$

$\begin{array}{lll}.28 & 1.50 & 12.00\end{array}$
Doz. $100 . \quad 1000$.

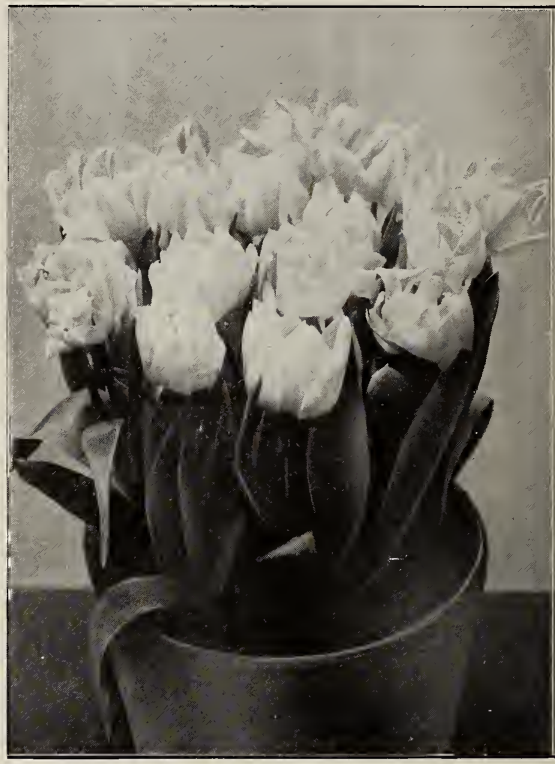

MURILLO.

Doz. 100.1000 .

2-Rubra Maxima, dazzling scarlet, splendid bedding variety. Height 10 inches...

1-Salvator Rosa, beautiful deep rose; extra. Height 10 inches $\ldots \ldots \ldots \ldots \ldots \ldots \ldots$

2-Titian, scarlet, edged yellow. Height 10

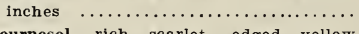

2-Tournesol, rich scarlet, edged yellow, very showy. Height 11 inches .......

2-Tournesol Yellow, bright yellow, slightly shaded orange. Height 11 inches ....

2-Vuurbaak, bright scarlet, with a slight flush of orange, when fully open, very handsome. Height 12 inches ........

2-William III, rich orange scarlet; extra. Height 12 inches .......ffi..........

$.30 \quad 1.65 \quad 13.20$

$.30 \quad 1.75 \quad 14.00$

$.37 \quad 2.15 \quad 17.20$

$.50 \quad 3.00 \quad 24.00$

$.42 \quad 2.45 \quad 19.60$

$.42 \quad 2.50 \quad 20.00$

$\begin{array}{lll}40 & 2.25 & 18.00\end{array}$

\section{LATE DOUBLE TULIPS.}

Very Tall Growing Varieties (Not Adapted for Foreing). Doz. 100.1000

Admiral Kinsbergen, red and yellow $\ldots \ldots \ldots \$ 0.42 \quad \$ 2.45 \quad \$ 19.60$

Blauwe Vlag (Lord Wellington), blue $\ldots . . \quad .95 \quad 5.50 \quad 44.00$

Mariage de ma Fille, white feathered crimson rose; very large and elegant. Height 14 inches .................. .80 $4.65 \quad 37.20$ Overwinnaar, blue and white, striped and

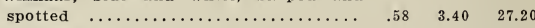

Paony Gold, red and gold striped $\ldots \ldots \ldots, \quad .30 \quad 1.75 \quad 14.00$

Preony red, scarlet $\ldots \ldots \ldots \ldots \ldots \ldots \ldots \ldots \ldots, \quad 30 \quad 1.75 \quad 14.00$

Yellow Rose, pure yellow $\ldots \ldots \ldots \ldots \ldots \ldots \ldots . .30 \quad 1.75 \quad 14.00$

From Detroit, Mich.- "Most beautiful collection as to size and color $I$ have ever seen."

"I am certainly delighted with the results obtained this year, and believe I have the most beautiful collection of Tulips, both as to size, variety and color, that I have ever seen. I have no objection to your using my letter as a testimonial, but think perhaps I could have given you one that is even stronger than the one I sent you the other day, without being at all extravagant language." C. D. B., 5-20-14.

Our bulbs have flourished in all sections of the U.S. 


\section{VARIEGATED-LEAVED TULIPS.}

The unusually attractive variegated foliage of these Tulips and the pleasing flowers are sure to make them popular in America once they are better known. Yellow Rose, particularly, deserves to be more planted-blooms late, bears sweet-scented double flowers of an excellent yellow.

\section{SINGLE.}

\begin{tabular}{|c|c|c|c|}
\hline Purple crown, golden yellow border ....... & $\begin{array}{l}\text { Doz. } \\
\$ 0.62\end{array}$ & $\begin{array}{l}100 . \\
\$ 3.50\end{array}$ & $\begin{array}{l}1000 \\
\$ 28.00\end{array}$ \\
\hline 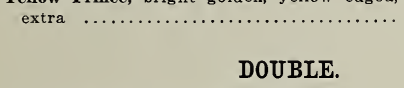 & .40 & 2.25 & 18.00 \\
\hline $\begin{array}{l}\text { a Candeur, silver variegated } \ldots \ldots \ldots \ldots \ldots \\
\text { Rex Rubrorum, flowers rosy red, leaves sil- }\end{array}$ & .62 & 3.50 & 28.00 \\
\hline $\begin{array}{c}\text { ver variegated, extra } \ldots \ldots \ldots \ldots \ldots \ldots \ldots \ldots \ldots \ldots \ldots \ldots \ldots \ldots \ldots \ldots \ldots \ldots \ldots \\
\text { Cournesol, rich scarlet, edged yellow gold } \\
\text { variegated } \ldots \ldots \ldots \ldots \ldots \ldots \ldots \ldots \ldots\end{array}$ & $\begin{array}{r}.42 \\
.75\end{array}$ & 2.50 & 20.00 \\
\hline Kellow Rose, edged yellow, very & .42 & 2.50 & 20.00 \\
\hline
\end{tabular}

\section{LATE SINGLE TULIPS.}

\section{BYBL00MS.}

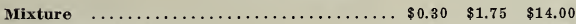
Named Varieties $\ldots \ldots \ldots \ldots \ldots \ldots \ldots \ldots \ldots \ldots, \quad .42 \quad 2.45 \quad 19.60$

\section{BIZARDS.}

These bizard Tulips, blooming in late May, are being used largely for naturalizing in borders and for oddity beds. Imagine the wonderful contrast of purple, crimson and brown markings on the yellow grounds of these large, showy flowers, you will realize why these are so popular in Europe and the British Isles for their outdoor effects and cutting purposes.

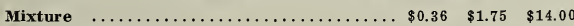
Named Varieties $\ldots \ldots \ldots \ldots \ldots \ldots \ldots \ldots \ldots \ldots . .42 \quad 2.45 \quad 19.60$

\section{BREEDERS.}

In fine named Varieties $\ldots \ldots \ldots \ldots \ldots \ldots \ldots \ldots .42 \quad 2.45 \quad 19.60$ Mixed, all colors $\ldots \ldots \ldots \ldots \ldots \ldots \ldots \ldots \ldots \ldots, \quad .35 \quad 1.75 \quad 14.00$

\section{PARROT (or Dragon) TULIPS.}

In the whole garden year nothing is more showy, more grotesque than the fragrant Parrot (or Dragon) Tulips. The waxy, irregular outlines; the brilliantly streaked petals, the oddly grotesque fashion in which they combine contrasting colors, are responsible for the growing interest being shown by the American public.

They bloom outdoors about the middle of May; have large flowers on graceful stems.

$\begin{array}{lll} & \text { Doz. } 100 . & 1000 \text {. }\end{array}$

Mixture $\ldots \ldots \ldots \ldots \ldots \ldots \ldots \ldots \ldots \ldots \ldots \ldots \ldots, \$ 0.22 \quad \$ 1.15 \quad \$ 9.75$

Amiral de Constantinople, scarlet $\ldots \ldots \ldots \ldots \quad .30 \quad 1.45 \quad 11.50$

Cramoise Brilliant, carmine $\ldots \ldots \ldots \ldots \ldots \ldots . \quad .30 \quad 1.45 \quad 11.50$

Gloriosa, red and yellow $\ldots \ldots \ldots \ldots \ldots \ldots \ldots . .30 \quad 1.45 \quad 11.50$

Lutea Major, yellow $\ldots \ldots \ldots \ldots \ldots \ldots \ldots \ldots \ldots . .30 \quad 1.45 \quad 11.50$

Markgraaf van Baden, red and yellow .... $\quad .30 \quad 1.45 \quad 11.50$

Monstre rubra major, scarlet, extra for forc-

ing and for bedding $\ldots \ldots \ldots \ldots \ldots \ldots \ldots \ldots . .30 \quad 1.45 \quad 11.50$

Perfecta, yellow and red $\ldots \ldots \ldots \ldots \ldots \ldots \ldots, .30 \quad 1.45 \quad 11.50$

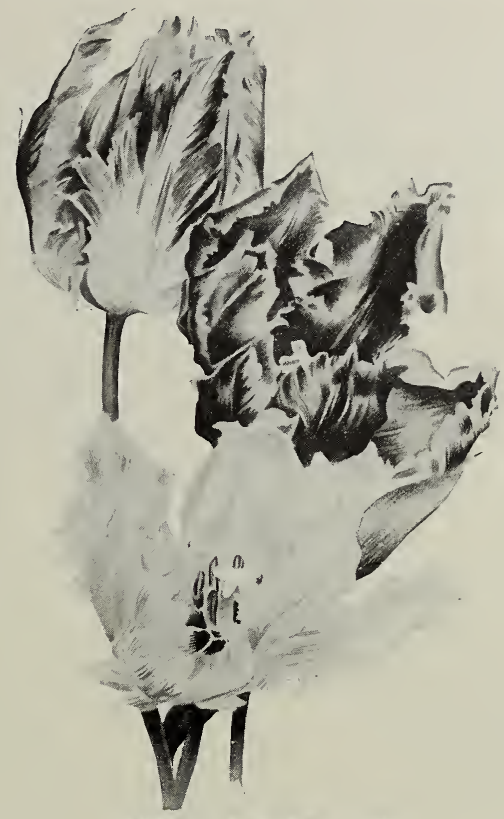

PARRoT (or Dragon) TULIP.

\section{REMBRANDT TULIPS.}

New Race of Striped Late Tulips.

\begin{tabular}{llll|rrr} 
Collection of 3 named sorts $\ldots \ldots \ldots \ldots \ldots \ldots \ldots$ & $\$ 0.75$ & $\$ 4.50$ & $\$ 36.00$ \\
Collection of 6 named sorts $\ldots \ldots \ldots \ldots \ldots \ldots \ldots$ & .80 & 4.75 & 38.00 \\
Finest Mixture & $\ldots \ldots \ldots \ldots \ldots \ldots \ldots \ldots \ldots \ldots \ldots$ & .62 & 3.50 & 28.00
\end{tabular}

\section{MAY-FLOWERING TULIPS.}

Amongst the following the most beautiful objects will be found for the herbaceous border as well as for other decorative purposes.

As their large, brilliant flowers are borne on long, sturdy stems, the May-flowering Tulips furnish excellent flowers for cutting during the middle of that month, when bloom is scarce. The Gesnerianas are distinctive for their various eyes or centres.

These Tulips should be planted outdoors only-they do not force well.

American Lac (Hobbema), large, satiny

lilac-salmon $\ldots \ldots \ldots \ldots \ldots \ldots \ldots \ldots \ldots \ldots \ldots \$ 1.10 \quad \$ 6.50 \quad \$ 52.00$ Beauty of America, creamy-white and pink, $.45 \quad 2.45 \quad 19.60$ Billietiana, yellow, flaked red .......... $.30 \quad 1.65 \quad 13.20$ Bouton d'or (Golden Beauty), the finest and

deepest golden-yellow tulip for cutting... $\quad .30 \quad 1.75 \quad 14.00$ Caledonia, bright orange-scarlet $\ldots \ldots \ldots \ldots . \quad .30 \quad 1.75 \quad 14.00$

From Quincey, Mass.- "Fine bulbs-beautifully packed."

"The Bulbs have arrived-they got here this morning. FINE BULBS-BEAUTIFULLY PACKED. I feel sure if they don't do well THE FAULT WILL BE OURS." A. M. T., 10-12-12.

From Duluth, Minn.- “Best I ever had."

"Two years ago I bought some Tulips of you, and they are the best I have ever had from onyone." D. R. S., 5-26-14. 


\section{MAY-FLOWERING TULIPS-Cont.}

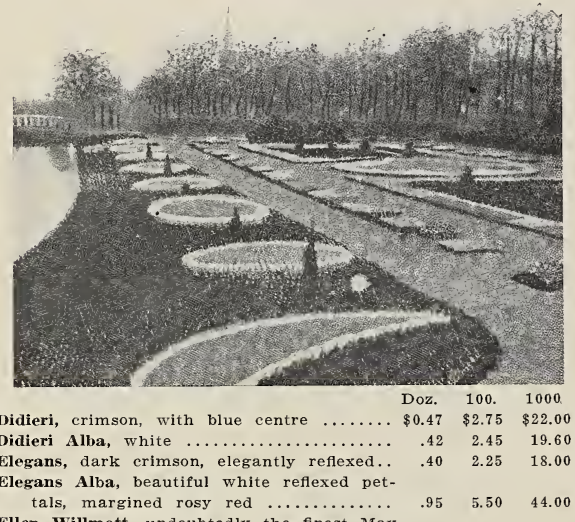

Ellen Willmott, undoubtedly the finest May flowering tulip; flowers very large, beautifully shaped and of a soft creamy yellow color, with a delicious fragrance...

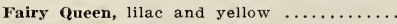

Florentina Odorata (Sylvestris), yellow,

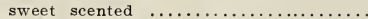

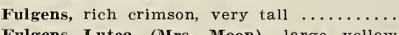

Fulgens Lutea (Mrs. Moon), large yellow, extra fine ...................... (Rosalind), rich crimson scarlet, with white eye, very lovely

Gesneriana Lutea, deep yellow, tall and handsome $\ldots \ldots \ldots \ldots \ldots \ldots \ldots \ldots . \ldots . \ldots . \ldots$

Gesneriana Lutea Pallida, large primrose

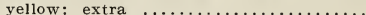

yellow; extra $\ldots \ldots \ldots \ldots \ldots \ldots \ldots \ldots \ldots$
black and yellow centre $\ldots \ldots \ldots \ldots \ldots \ldots$
.30
$.80 \quad 4.75 \quad 38.00$ $50 \quad 3.00 \quad 24.00$

$.38 \quad 2.15 \quad 17.20$

$.40 \quad 2.25 \quad 18.00$

$1.10 \quad 6.50 \quad 52.00$

$.30 \quad 1.75 \quad 14.00$

$35 \quad 2.00 \quad 16.00$

$70 \quad 4.00 \quad 32.00$

Dos

Gesneriana Rosea, rosy carmine, black

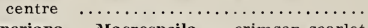

Gesneriana Macrospeila, crimson-scarlet Gesneriana Major (Spathulata), rich crimson scarlet, blue black centre; very

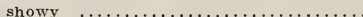

Golden Crown, golden yellow, edged red...

Golden Eagle, deep yellow ..............

Greigi, gigantic flower, scarlet-orange, foli-

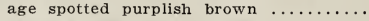

Ingleseombe Pink, salmon rose .........

Ingleseombe Scarlet, brilliant scarlet, black

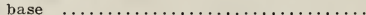

Inglescombe Yellow, may be called the yellow Darwin tulip, large flowers of a perfect form, glossy canary yellow, very beautiful $\ldots \ldots \ldots \ldots \ldots \ldots \ldots \ldots \ldots \ldots \ldots \ldots \ldots$ creamy yellow changing to dark magenta $\ldots \ldots \ldots \ldots \ldots \ldots \ldots \ldots \ldots \ldots \ldots \ldots \ldots$

La Candeur (Parisian White), pure white, afterwards suffused with rose .........

La Merveille, scarlet suffused with apricot

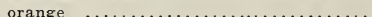

Mrs. Moon, large yellow, extra fine .......

Parisian Yellow, rich lemon-yellow, with a deeper centre $\ldots \ldots \ldots \ldots \ldots \ldots \ldots \ldots$

Picote (Mraiden's Blush), white, graceful recurved petals, margined rose, elegant

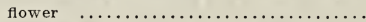

Primrose Beauty, belongs to the same type as Miss Wilmott, color soft primrose, changing to white.$\ldots \ldots \ldots \ldots \ldots \ldots$.

Retroflexa, light yellow with elegantly recurved petals, fine for cutting ........

Royal White, pure white with yellow centre, Scarlet Mammouth, large crimson, dwarf ..

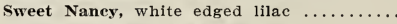

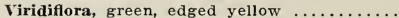
Viridiflora Praecox, beautiful large flowers, soft green, edged yellow ............

Vitellina, pale primrose, passing off pure white, tall and exceedingly handsome..

Zomersehoon, flesh color, striped with sal-

mon red. 40 cents each .......... 4.75

100. 1000 .

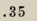

8.00

1.7514 .00

$\begin{array}{lll}1.50 & 9.00 \quad 70.00\end{array}$

$40 \quad 2.25 \quad 18.00$

$\begin{array}{lll}50 & 2.95 \quad 23.60\end{array}$

$1.00 \quad 6.00 \quad 48.00$

$1.25 \quad 10.00$

.3

$.23 \quad 1.25 \quad 10.00$

$\begin{array}{lll}1.10 & 6.50 & 52.00\end{array}$

$.30 \quad 1.65 \quad 13.20$

$.30 \quad 1.60 \quad 12.50$

$\begin{array}{lll}40 & 2.25 & 18.00\end{array}$

$\begin{array}{lll}.38 & 2.15 & 17.20\end{array}$

$\begin{array}{lll}.67 & 3.75 & 30.00\end{array}$

$\begin{array}{lll}.47 & 2.75 & 22.00\end{array}$

$\begin{array}{lll}.25 & 1.35 & 10.80\end{array}$

$\begin{array}{lll}.55 & 3.25 & 26.00\end{array}$

$4.50 \quad 25.00$

$.85 \quad 5.0$

40.00

\section{DARWIN TULIPS}

We strongly recommend this class of Tulips for garden decoration in groups, in the herbaceous border and amongst shrubs.

Assortment in 10 fine named varieties . . . . . . $30 \quad 1.50 \quad 12.75$

Ariadne, fiery scarlet red $\ldots \ldots \ldots \ldots \ldots \ldots \ldots . .85 \quad 5.00 \quad 40.00$

Ant. de Barry, brownish velvet red ....... $40 \quad 2.45 \quad 19.60$

Ant. Roozen, lovely rose tinged apricot;

Andromeda, dark violet-red flower of strong

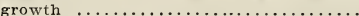

Baronne de la Tonnaye, vivid rose .........

Bruno, a large deep brown-red flower of nice shape ................... $1.00 \quad 5.75$

C. J. Salter, bright rose, fine flower ....... $.42 \quad 2.45$

City of Haarlem, brilliant scarlet with a pure white centre, very large ....... $4.50 \quad 35.00$

Clara Butt, soft delicate pale salmon rose, a flower of remarkable beauty .........

Cordelia, glowing violet-erimson, very hand

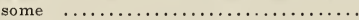

Donders, crimson, dark violet centre .......

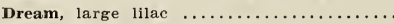

Edmee, vivid rose pink $\ldots \ldots \ldots \ldots \ldots \ldots \ldots$

Etna, bright red $\ldots \ldots \ldots \ldots \ldots \ldots \ldots \ldots \ldots$
Ergusti, dull violet, inside of petals darker, white base

$\begin{array}{rrr}.72 & 4.25 & 34.00 \\ .42 & 2.50 & 20.00 \\ & & \\ 1.00 & 5.75 & \\ .42 & 2.45 & 19.60 \\ & & \\ 4.50 & 35.00 & \\ & & \\ .42 & 2.50 & 20.00 \\ & & \\ .70 & 4.00 & 32.00 \\ .47 & 2.75 & 22.00 \\ .62 & 3.50 & 28.00 \\ .80 & 4.75 & 38.00 \\ .75 & 4.50 & 36.00 \\ & & \end{array}$

$1.05 \quad 6.25$
Europe, bright earmine red; extra ........ Doz. $\begin{array}{rrr}100 . & 1000 . \\ 3.45 & 27.50\end{array}$

Farncombe Sanders, fiery scarlet $\ldots \ldots \ldots \ldots .72 \quad 4.25 \quad 34.00$

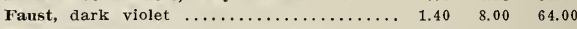

Fra Angelico, dark brownish-black $\ldots \ldots \ldots .67 .67 \quad 3.50 \quad 28.00$

Glory, brilliant scarlet .............. $50 \quad 3.00 \quad 25.20$

Glow, brilliant glowing vermilion, centre blue, margined white $\ldots \ldots \ldots \ldots \ldots \ldots$

Gudin, light blue, slightly edged with an even paler shade of same color .......

Gretchen, large globular flower; outside blush, inside soft blush; very beautiful,

Gustav Dore, bright rose .............

Hecla, deep crimson maroon; very beautiful,

Isis, bright crimson $\ldots \ldots \ldots \ldots \ldots \ldots \ldots \ldots$

Kate Greenaway, white flushed lilac; very

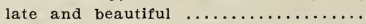

La Candeur (White Queen), lovely soft white, slightly tinged blush, anthers black; a beautiful, large, globular, erect

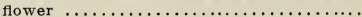

Lantern, silvery lilac, changing to white ...

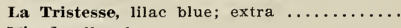

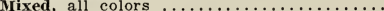

$\begin{array}{lll}.53 & 3.10 & 26.00\end{array}$

$1.10 \quad 6.50 \quad 52.00$

$\begin{array}{lll}.30 & 1.65 & 13.20\end{array}$

$\begin{array}{lll}.50 & 3.00 & 24.00\end{array}$

$\begin{array}{lll}.42 & 2.50 & 20.00\end{array}$

$.95 \quad 5.50 \quad 44.00$

$.47 \quad 2.75 \quad 22.00$

$\begin{array}{lll}.72 & 4.25 & 34.00\end{array}$

$\begin{array}{lll}40 & 2.25 & 18.00\end{array}$

$30 \quad 1.50 \quad 12.75$
$.95 \quad 5.50 \quad 44.00$

From Philadelphia, Pa.-_"Favorable comment regarding size and color."

"The bulbs purchased from you last fall have given remarkable satisfaction. The Tulips, especially the Murillo doubles, and the Darwins, in my garden have given rise to a great deal of very favorable comment regarding size and colors." H. S. T., 5-11-15. 


\section{DARWIN \\ TULIPS--Cont.}

Grown for cut flowers, they will prove very valuable at a time that our gardens yield so little to decorate our rooms. They flower during the middle part of May, a time in which the spring flowers are over and the summer flowers, such as roses, have not yet come in.

Growing to a height of a couple feet, with perfectly colored flowers double the size of an ordinary Tulip, the Darwin deserves to be thoroughly interspersed along the borders. It is well to put Darwin Tulips at the back-other May-flowering Tulips in front, and a border of early Tulips if you want almost continuous bloom, while the other plants are getting started.

By slowly forcing in pots they may be had in bloon in March or even earlier; most of the varieties improve in color by protection under glass or canvas. The list of varieties we offer is carefully selected and includes nothing but fine varieties. We have discarded a great many varieties which we considered inferior to those we now offer.

La Tulipe Noire (The Black

Tulip), very large ..... \$2.75 $\$ 15.00$

roveliness, soft rosy car-

mine, extra ......... $.47 \quad 2.75 \quad 22.00$

Marconi, violet white cen-

tre, large $\ldots \ldots \ldots \ldots \ldots \ldots \quad .95 \quad 5.50 \quad 44.00$

IIassachusetts, beautiful

light rose $\ldots \ldots \ldots \ldots \ldots \ldots \quad .62 \quad 3.50 \quad 28.00$

Massenet, apple blossom

extra $\ldots \ldots \ldots \ldots \ldots \ldots \ldots \quad .85 \quad 5.00 \quad 40.00$

May Queen, soft rose, large

and beautiful $\ldots \ldots \ldots \ldots . \quad .58 \quad 3.25 \quad 26.00$

Melicette, deep lilac ..... $1.35 \quad 7.75 \quad 62.00$

Ime. Krelage, vivid pink,

light bordered, extra $\ldots . .47 \quad 2.75 \quad 22.00$

Irs. Cleveland, delicate pink $\ldots \ldots \ldots \ldots \ldots \ldots \ldots, \quad .70 \quad 4.00 \quad 32.00$

Nauticus, purplish rose,

large $\ldots \ldots \ldots \ldots \ldots \ldots, \quad .40 \quad 2.25 \quad 18.00$

Nora Ware, silvery lilac, shaded white, extremely beautiful $\ldots \ldots \ldots \ldots \ldots \ldots \ldots$

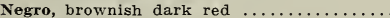

North Dacotah, fiery red, white basal blotch

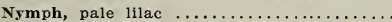

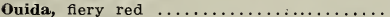

Painted Lady, soft milky white flowers on dark purple stems; flowers resemble the beautiful Nymphaea or Waterlily .......

Peter Barr, bright rose $\ldots \ldots \ldots \ldots \ldots \ldots \ldots$

Pride of Haarlem, large flower, dazzlin cerise-scarlet $\ldots \ldots \ldots \ldots \ldots \ldots \ldots \ldots$

Prof. Francis Darwin, salmon scarlet ......

Psyche, delicate pink, very beautiful .......

Queen of the Roses, rose; extra ...........

Rev. Ewbank, vivid heliotrope lilac, light

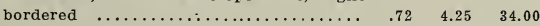

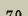

.70

42

.42

.55

.50

$\begin{array}{lll}47 & 2.75 & 22.00\end{array}$

$\begin{array}{lll}.70 & 4.00 & 32.00\end{array}$

$85 \quad 5.00 \quad 40.00$

$.47 \quad 2.75 \quad 22.00$

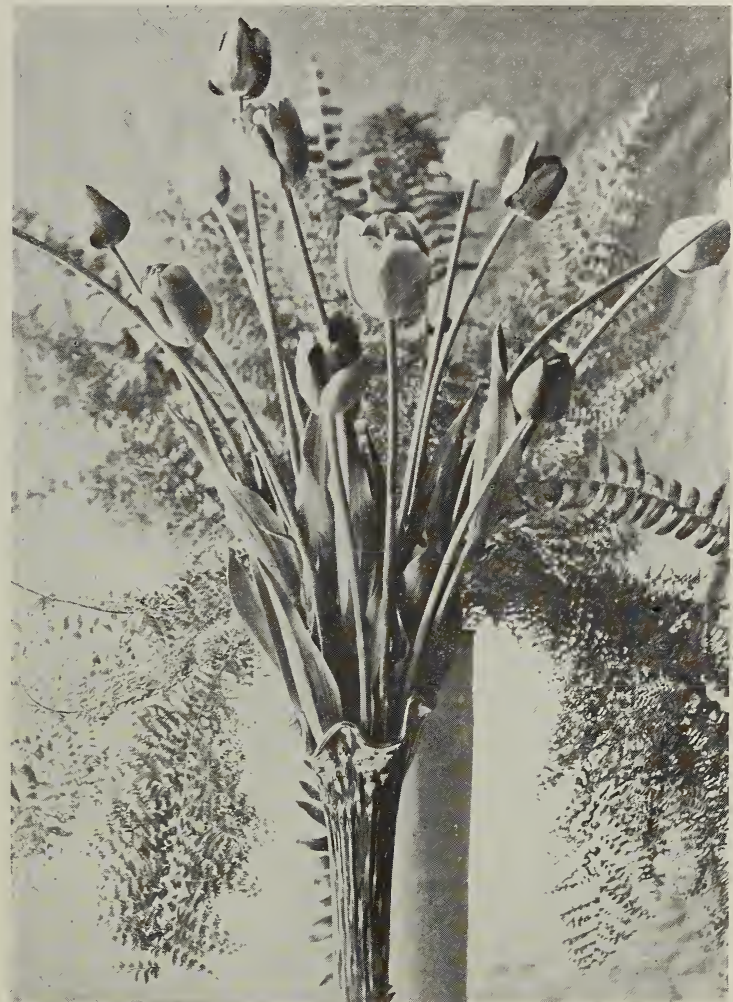

Doz. $100 . \quad 1000$

Sieraad van Flora, large flower, vivid rosy

red; one of the earliest $\ldots \ldots \ldots \ldots \ldots \ldots .85 \quad 5.00 \quad 40.00$

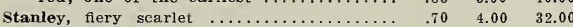

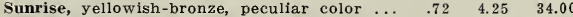

Therese Schvartze, soft heliotrope lilac $\ldots . \quad .95 \quad 5.50 \quad 44.00$

The Sultan, black (may be called the black tulip) $\ldots \ldots \ldots \ldots \ldots \ldots \ldots \ldots \ldots \ldots \ldots \ldots . .35 \quad 2.00 \quad 16.00$

William Copland, lilac, early $\ldots \ldots \ldots \ldots \ldots . \quad .80 \quad 4.75 \quad 38.00$

Wedding Veil, nearly pure white $\ldots \ldots \ldots \ldots . .50 \quad 3.00 \quad 24.00$

$\begin{array}{lllll}\text { William Pitt, scarlet red, excellent forcer.. } & .67 & 3.75 & 30.00\end{array}$

Yellow Perfection, light bronze yellow, edged golden, extremely beautiful $\ldots . .6 \quad 1.25 \quad 7.00 \quad 56.00$

Zephir, pretty soft rose $\ldots \ldots \ldots \ldots \ldots \ldots \ldots, \quad .72 \quad 4.25 \quad 34.00$

Zulu, violet-black, very distinct shape; a splendid and very remarkable flower $\ldots \begin{array}{llll}1.25 & 7.00 & 56.00\end{array}$

From U. S. Department of Agriculture, Bureau of Plant Industry, Washington, D. C.

"I have to-day passed vouched in your favor for .... The bulbs furnished by your firm to this Department last fall were entirely satisfactory, as shown by the results secured on the Department's trial grounds this spring. You will receive check from oụr Disbursing Office in due course." R. A. O., Acting Assistant in Charge, 5-17-13.

From Germantown, Pa.-_A fine display this spring."

"The lot of Bulbs I bought from you made a fine display this spring. I will call on you in the fall." G. H. L., 5-12-15. 


\section{CROCUS. Named Varieties}

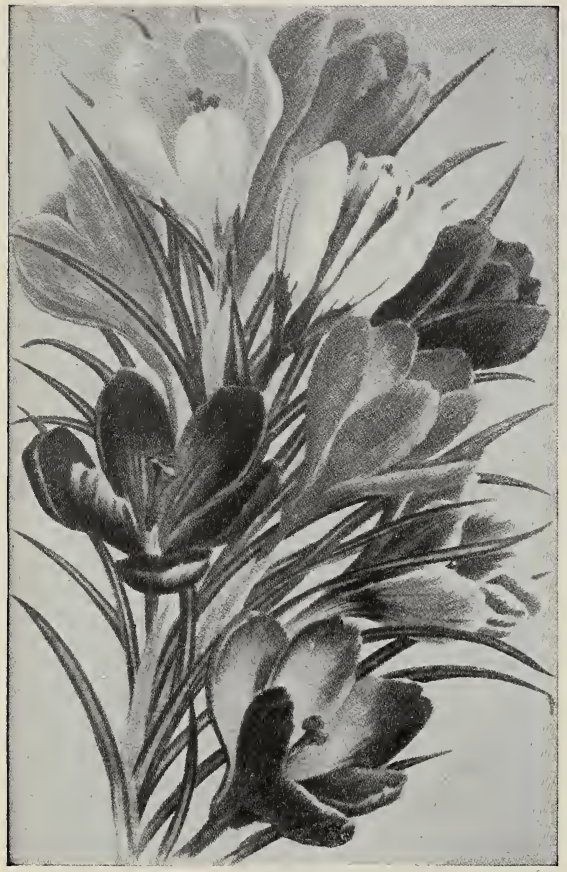

Our Crocus prices are not the lowest, but for the quality of stock we furnish they are very moderate, and we question if such quality can be had except direct from growers like W. \& $\mathbf{K}$.

You will have a pleasing surprise the first spring day next year if you scatter Crocuses liberally across your lawn, and in colonies along the front of your flower beds now. Don't confine yourself to the yellow sorts alone-remember that a touch of blue color in early spring is most welcome; that the white, purple and striped and spotted sorts offer an excellent forecast of your garden season of pleasure.

Plant Crocus on the lawn, 2 inches deep, and 3 inches apart in colonies, blending away to intervals of six inches, if you want an old and pleasing effect. Remember it does them no harm to be cut down, when the lawn needs its first application of the mower.

Albion, purple $\quad$ Doz. $100 . \quad 1000$

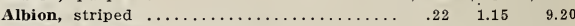

Baron von Brunow, dark blue $\ldots \ldots \ldots \ldots \ldots . .28 \quad 1.50 \quad 12.00$

Caroline Chisholm, white $\ldots \ldots \ldots \ldots \ldots \ldots . .23 \quad 1.25 \quad 10.00$

Dandy, purplish bordered white $\ldots \ldots \ldots \ldots . \quad .28 \quad 1.50 \quad 12.00$

David Rizzio, purple $\ldots \ldots \ldots \ldots \ldots \ldots \ldots \ldots \ldots \quad .28 \quad 1.50 \quad 12.00$

Grande Vedette, blue $\ldots \ldots \ldots \ldots \ldots \ldots \ldots \ldots \ldots .28 \quad 1.50 \quad 12.00$

King of the Whites, white $\ldots \ldots \ldots \ldots \ldots \ldots \ldots . .23 \quad 1.25 \quad 10.00$

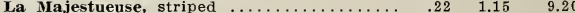

Madame Mina, violet striped ............... $22 \quad \mathbf{1 . 1 5} \quad 9.20$

Mont-Blanc, white .................. $23 \quad 1.25 \quad 10.00$

Non plus ultra, blue, bordered white $\ldots \ldots . \quad .28 \quad 1.50 \quad 12.00$

Othello, dark purplish black $\ldots \ldots \ldots \ldots \ldots \ldots . .28 \quad 1.50 \quad 12.00$

Purpurea grandiflora, dark purple $\ldots \ldots \ldots \ldots .40 \quad .40 \quad 2.25 \quad 18.00$

Queen Victoria, white $\ldots \ldots \ldots \ldots \ldots \ldots \ldots \ldots \ldots .23 \quad 1.25 \quad 10.00$

Sir John Franklin, blue, large $\ldots \ldots \ldots \ldots \ldots . .28 \quad 1.50 \quad 12.00$

Sir Walter Scott, striped $\ldots \ldots \ldots \ldots \ldots \ldots \ldots . .22 \quad 1.15 \quad 9.20$

Iixed white $\ldots \ldots \ldots \ldots$ Doz. 100.

Mixed blue \& purple $\ldots \ldots \ldots \ldots \ldots \ldots \ldots \ldots \ldots . .24 \quad 1.30 \quad 10.40$

Mixed striped $\ldots \ldots \ldots \ldots \ldots \ldots \ldots \ldots \ldots \ldots \ldots \ldots, \quad .18 \quad 1.00 \quad 8.00$

Mixed extra giant flowering, all colors $\ldots \ldots, \quad .18 \quad 1.00 \quad 8.00$

\section{YELLOW CROCUS.}

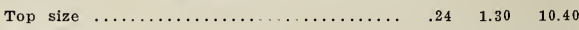

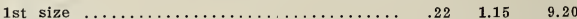

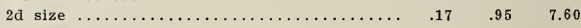

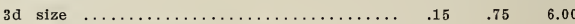

\section{NARCISSUS POETAZ}

Originated from a cross of Narcissus Poeticus and the Polyanthus Narcissi.

This new strain may be considered to be an improved race of the old Polyanthus Narcissi. They are perfectly hardy, have many-flowered stems and larger sweet-scented flowers, and fit for pot culture as well as for forcing.

Doz. 100 . Alsace, white, cup lemon yellow, bordered orange. $\$ 1.50 \quad \$ 10.00$
Doz. 100 .

Aspasia, white, cup deep yellow .............\$0.65 \$3.50

Elvira, white with yellow cup $\ldots \ldots \ldots \ldots \ldots \ldots \ldots . .70 \quad 3.75$

Ideal, white with orange cup $\ldots \ldots \ldots \ldots \ldots \ldots \ldots .1 .50 \quad 8.00$

Irene, yellow with orange cup .............. $1.40 \quad 7.50$

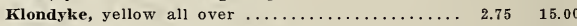

Profusion, white with orange cup $\ldots \ldots \ldots \ldots \ldots \ldots, 1.75 \quad 10.00$

Triumph, white with yellow cup ............ $1.30 \quad 7.00$

\section{NARCISSI (DAFFODILS).}

The Narcissus vies closely with the Tulip and Hyacinth for spring honors. Dainty in color, graceful in habit, it furnishes long-stemmed flowers which are highly desirable for cutting.

The poeticus varieties are very sweet-scented and like all the Narcissi, are especially well adapted for naturalizing in the semi-shady spots where the suns rays are slightly broken.

It is well to be remembered that Tulips and Hyacinths need more sun and lighter soil than the Narcissus, and to arrange your planting accordingly if you want flowers that excel all in the neighborhood.

In planting do not break off the small bulbs which adhere to the sides of the Narcissus bulb-as these will send up blooms and provide for growth of a small clump from each bulb. Strangely, the American habit seems to be to separate the small attached bulb from the parent, losing its vitality largely and preventing the increasing clump, which Narcissi form.

From Attica, N. Y.- "I want more-send catalog."

"My Tulips I received last fall from Holland are just beautiful. They are all in full bloom. I want more, so kindly send me your new catalog of Bulbs." G. M. R., 5-17-15.

From Lancaster, Pa.- "Florist never had finer bulbs."

"The Bulbs received and I must say that I am pleased with them. If they give blooms to the size of Bulbs I will have fine stock for Easter. I never had finer Bulbs." J. F. J., 10-19-14. 


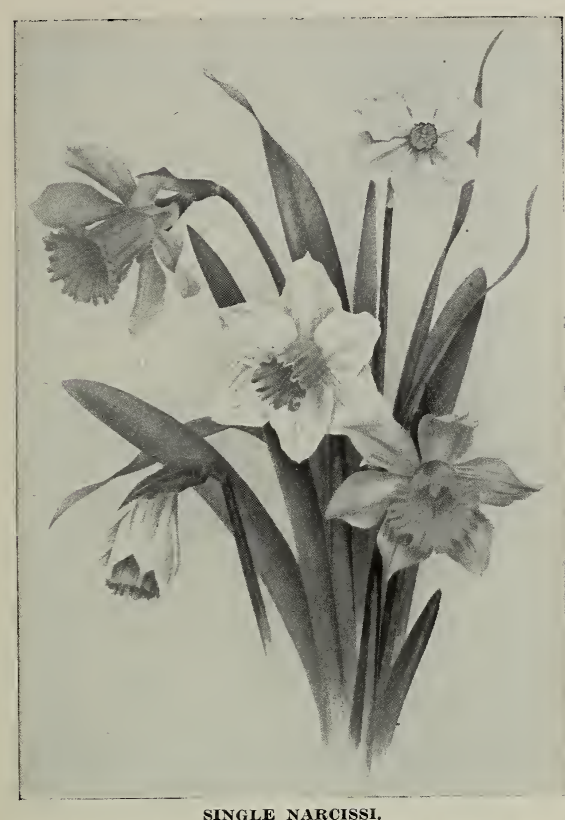

This grouping shows three of the best single Narcissi. The bud in the lower left-hand corner is the bicolor Grandis. From the illustration you get only a feeble idea of the beautiful contrast between the white perianth and the projecting yellow trumpet. The cut of the same variety in the centre of the illustration indicates the striking contrast between the bright yellow trumpet and the surrounding white perianth when fully opened.

In the upper left-hand corner and lower right are shown two views of the Golden Spur Narcissus which is of a deep yellow color. This is the best of all yellow Daffodils. Blooms early outdoors and forces easily.

In the upper right-hand corner is shown the beautiful Poeticus Ornatus (listed under Poeticus varieties above). Exceptional for forcing, fully three weeks before the ordinary Poeticus (or Pheasant's Eye) is in bloom. Ornatus produces beautiful white blooms with the distinctive yellow "eye" edged with red.

\section{SINGLE NARCISSI.}

rixture $\quad$ Doz. 100.1000. RED CUPPED NARCISSUS.

(Complete list on page 18.)

INCOMPARABILIS VARIETIES.

Ineomparabilis Barri Conspicuus, sulphur $\ldots \begin{array}{llll}\$ 0.20 & \$ 1.10 & \$ 8.80\end{array}$ $\begin{array}{lllll}\text { Cynosure, yellowish } & \ldots \ldots & .20 & 1.10 & 8.80\end{array}$ Sir Watkin, yellow cup, sul$\begin{array}{lllll}\text { phur perianth } \ldots \ldots \ldots \ldots & .42 & 2.50 & 20.00\end{array}$ Albus Stella, white $\ldots \ldots \ldots . .18 \quad 1.00 \quad 8.00$ Typus, yellow ............

Leedsii Elegans, white and sulphur $\ldots \ldots \ldots, \quad .20 \quad 1.10$
POETICUS VARIETIES. (Poet's Narcissus.)

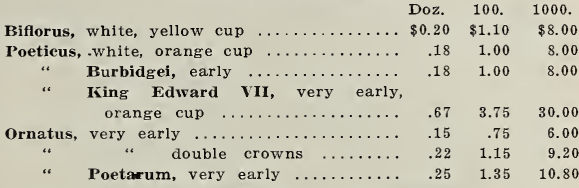

\section{TRUMPET VARIETIES.}

Ard Righ (Irish King), very early; extra .. Bicolor grandis, yellow trumpet, white perianth

Empress, white and yellow, large.

Horsfieldi, white and yellow ......

Victoria, grand $\ldots \ldots \ldots \ldots \ldots \ldots$.

Emperor, yellow, large flower ....

Golden Spur, golden yellow selected doub!e crowns $\ldots \ldots \ldots \ldots \ldots \ldots$.

" first size $\ldots \ldots \ldots \ldots \ldots \ldots \ldots$

Glory of Leiden, deep golden-yellow, very

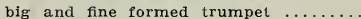

$\begin{array}{lll}45 & 2.75 & 22.00\end{array}$

$\begin{array}{lll}.30 & 1.75 & 14.00\end{array}$

$\begin{array}{lll}45 & 2.75 & 22.00\end{array}$

$\begin{array}{lll}35 & 2.00 & 16.00\end{array}$

$\begin{array}{lll}.70 & 4.00 & 32.00\end{array}$

$.50 \quad 3.00 \quad 24.00$

$\begin{array}{lll}.70 & 4.00 & 32.00\end{array}$

$\begin{array}{lll}40 & 2.25 & 18.00\end{array}$

Henry Irving, fine yellow, early $\ldots \ldots \ldots \ldots .42 \quad 2.50 \quad 20.00$

King Alfred, a most desirable early Daffodil

of an uniform rich golden-yellow; very

large, refined flower and most vigorous

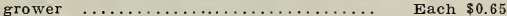

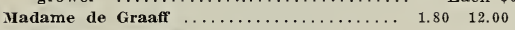

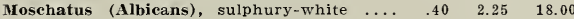

Obvallaris, yellow, very early $\ldots \ldots \ldots \ldots \ldots, \quad .47 \quad 2.75 \quad 22.00$

Pseudo (Lent Lily), perianth sulphur, trum-

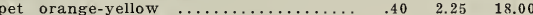

scoticus, perianth white, trumpet yellow... $\quad .50 \quad 3.00 \quad 24.00$

Trumpet Major, yellow, fine trumpet ..... $40 \quad .40 \quad 2.25 \quad 18.00$

“ Maximus, large golden-yellow $\quad \ldots \quad .42 \quad 2.50 \quad 20.00$

“. Nana, yellow, dwarf .............. $.25 \quad 1.35 \quad 10.80$

Princeps, pale yellow $\ldots \ldots \ldots \ldots-28 \quad 1.50 \quad 12.00$

Van Sion, golden yellow, very early for

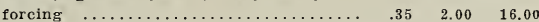

\section{DOUBLE NARCISSI.}

Among the double Narcissi none is so well-known as the double Von Sion, of which a side view is shown at left and a front view in the lower centre of this picture. This is the double yellow daffodil so popular in America around the Easter season, and for this purpose it is forced by florists in larger quantities than any other Narcissus.

The orange Phoenix shown at the top of this illustration shades from white to deep orange with a blending of yellow between; the Sulphur Phoenix shown at the right, from white to sulphur yellow. Of these two, the Orange Phoenix is generally considered the more satisfactory for forcing-but in common with all other double Narcissus, any of these varieties are easily grown outdoors. Doz. 100. 1000. Mixture $\ldots \ldots \ldots \ldots \ldots \ldots \ldots \ldots \ldots \ldots \ldots \ldots \ldots \ldots \$ 0.25 \quad \$ 1.35 \quad \$ 12.00$

Albo pleno odorato, white. The gardenia

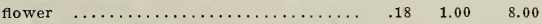

Capax Plenus, "Queen Ann's double Daffo-

dil," star-shaped, lemon .......... Each $\$ 0.50$

Incomparable, Butter and Eggs $\ldots \ldots \ldots \ldots .28 \quad 1.55 \quad 12.40$

Orange Phoenix, yellow and orange ...... $.30 \quad 1.75 \quad 14.00$

Pallidus plenus, sulphur and orange $\ldots \ldots \ldots . .42 \quad .42 \quad 2.50 \quad 20.00$

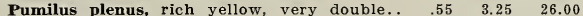

Sulphur Phoenix, sulphury white $\ldots \ldots \ldots \ldots . .35 \quad 2.00 \quad 16.00$

Van Sion, double yellow trumpet, extra se-

lected bulbs ..................... .80 $4.75 \quad 42.00$

$\begin{array}{lllll}\text { Van Sion, double yellow trumpet, first size, } & .42 & 2.50 & 20.00\end{array}$ $\begin{array}{lllll}\text { 8.80 Van Sion, double yellow trumpet, second size, } & .30 & 1.75 & \mathbf{1 4 . 0 0}\end{array}$

From Americus, Ga.- "Have already referred others to you."

"The bulbs I bought from you in the fall were beautiful, and I certainly want to order more this year. Please mail me your new cataiog of Narcissus, Daffodils and Hyacinths as soon as it is out. I have already referred your house to several admirers of your bulbs." Mrs. D. R. A., 4-20-15. 


\section{DOUBLE NARCISSI.}

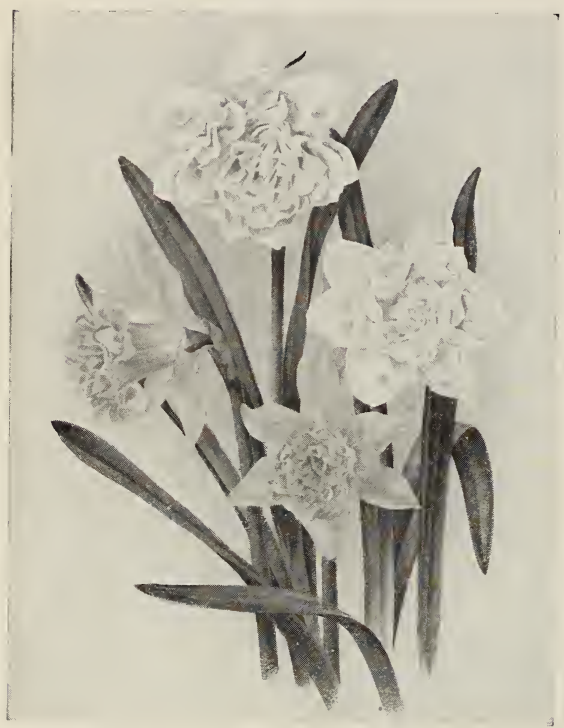

\section{POLYANTHUS NARCISSI. Bunch Flowered Narcissus.}

Bathurst, yellow ........................... Doz.

Grand Uonarque, white

Grand Primo, sulphur

Grand Soleil d'or, golden-yellow

Her Majesty, white with yellow cup

Jaune Supreme, yellow

Newton, bright yellow

Queen of the Netherlands, white, early

White Pearl, white

Mixed, all colors ...........

Mixed, white

Mixed, yellow

\section{RED CUPPED NARCISSUS}

Barri-Delight, pure white, flat, orange-yellow broadly scarlet edged cup $\ldots \ldots \ldots \ldots \ldots \ldots \ldots . \$ 0.85 \quad \$ 6.00$

Barri-Seagull, pure white, cup candy, edged apricot, very fine

Barri-Valeria, very late, large greenish-yellow eve, with distinct rim of red, perianth white

Incomparabilis-Flambeau, glowing orange cup ... Incombarabilis-Red Crown, white, cup red-orange, Incomparabilis-Torch, striking variety, petals yellow, orange-scarlet cup $\ldots \ldots \ldots \ldots \ldots \ldots \ldots$. Incomparabilis-Will scarlet, large fiery orange-red cup $\ldots \ldots \ldots \ldots \ldots \ldots \ldots \ldots \ldots \ldots \ldots \ldots \ldots . \ldots \ldots$
JONQUILS.

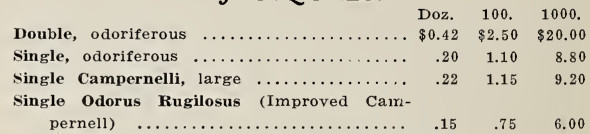

\section{DOUBLE ANEMONES.}

\begin{tabular}{|c|c|c|}
\hline In 6 fine named Varieties... & $\$ 0.30$ & $\$ 1.80$ \\
\hline Ceres, rosy white $\ldots \ldots \ldots \ldots$. & .30 & 1.80 \\
\hline Feu Superbe, scarlet $\ldots \ldots \ldots \ldots \ldots$ & .40 & 2.25 \\
\hline King of the Blues, blue $\ldots \ldots \ldots \ldots \ldots \ldots \ldots$ & .30 & 1.80 \\
\hline Rosette, soft rose $\ldots \ldots \ldots \ldots \ldots \ldots \ldots \ldots \ldots \ldots$ & .30 & 1.80 \\
\hline Sir Joseph Paxton, violet $\ldots \ldots \ldots \ldots \ldots \ldots \ldots \ldots$ & .40 & 2.25 \\
\hline Sir Robert Peel, lilac $\ldots \ldots \ldots \ldots \ldots \ldots \ldots \ldots \ldots$ & .40 & 2.25 \\
\hline Surprise, scarlet, extra $\ldots \ldots \ldots \ldots \ldots \ldots \ldots \ldots$ & .40 & 2.25 \\
\hline The Bride, pure white $\ldots \ldots \ldots \ldots \ldots \ldots \ldots \ldots$ & .40 & 2.25 \\
\hline All Colors Mixed $\ldots \ldots \ldots \ldots \ldots \ldots \ldots$ & .25 & 1.60 \\
\hline Scarlet, Mixed & .25 & 1.60 \\
\hline Blue, Mixed . & .25 & 1.60 \\
\hline
\end{tabular}

\section{SINGLE ANEMONES.}

All colors, mixed $\ldots \ldots \ldots \ldots \ldots \ldots \ldots \ldots \ldots \ldots, \$ 0.20 \$ \$ 1.20$ Scarlet, $\operatorname{mixed} \ldots \ldots \ldots \ldots \ldots \ldots \ldots \ldots \ldots \ldots \ldots, .20 \quad 1.20$

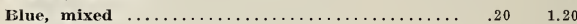

Violet, mixed $\ldots \ldots \ldots \ldots \ldots \ldots \ldots \ldots \ldots \ldots \ldots . .20 \quad 1.20$

The Bride, pure white $\ldots \ldots \ldots \ldots \ldots \ldots \ldots \ldots \ldots .25 \quad 1.20$

\section{ANEMONES DE CAEN.}

All colors, mixed $\ldots \ldots, \ldots, \ldots, \ldots, \ldots, \ldots, \ldots, 25$

$\$ 1.50$

\section{ANEMONES ST. BRIGID.}

If you will try this wonderful new race of half double anemones, particularly in a cool, shaded spot around the shrubs and bushes, you will find a pleasing surprise in wonderful scarlet, purple and cerise flowers, of a type that is still rare in America.

Splendid mixture

Doz. $\quad 100$ $\$ 0.45 \$ 2.50$

\section{RANUNCULUS.}

The Ranunculus Grandiflora is a brilliant feature of the fine gardens on the continent, but is comparatively little known, at its best, in America. In the opinion of American experts who have studied the conditions under which they flourish abroad, it should be easy to grow them in California and the entire Southwest, where the rainy season most closely duplicates those of their native Asia Minor. In other sections, growing Ranunculus outdoors requires care and skill-is a worth while test of expert gardening ability.

As a forcing flower Ranunculus has been standard for a half-century, there is no reason why any one should have trouble in getting a profusion of blooms with Ranunculus in his greenhouse.

Doz. 100.

Persian, in 6 fine named varieties $\ldots \ldots \ldots \ldots \ldots \ldots .20 \quad \$ 1.20$

Persian, all colors mixed $\ldots \ldots \ldots \ldots \ldots \ldots \ldots \ldots, \quad .15 \quad .80$

French, in 6 fine named varieties $\ldots \ldots \ldots \ldots \ldots \ldots, .20 \quad 1.20$

French, all colors mixed $\ldots \ldots \ldots \ldots \ldots \ldots \ldots \ldots \ldots, \quad .15 \quad .80$

Turban, in 6 named varieties $\ldots \ldots \ldots \ldots \ldots \ldots \ldots, .25 \quad 1.40$

Turban, all colors mixed $\ldots \ldots \ldots \ldots \ldots \ldots \ldots \ldots, \quad .20 \quad 1.20$

Fiom Montgomery, Ala.- "Never saw such fine stock before."

"My order of bulbs was received several days ago, and I must say that I have never seen such fine stock in all of my flower experience. They have just made me 'flower crazy' going around showing my friends what fine specimens they are. Now accept my most hearty thanks for sending such select stock." J. P. M., 11-27-11.

From Canandaigua, N. Y.-“The finest blooms I have ever seen."

"I wish to say that the bulbs I got from you last fall were entirely satisfactory and produced the finest blooms I have ever had-better than from hyacinths I have paid twenty-five cents each for." G. W., 2-25-13. 


\section{IRIS}

In few flowers is there more world-wide interest than in the Iris. The German Iris, or Flag, was the first to interest any large number of American flower lovers, but the more graceful Japanese types have been introduced into most American gardens long before this.

Admittedly the ideal Iris is Iris Hispanica, or Iris Anglica, the growing of which has been confined largely to American florists due to the feeling that the plant was difficult to raise.

True, the Spanish Iris requires more winter protection than the sturdy German types, but it is worth the effort, if you will plant in September and give it a rich, moist soil and good winter protection, you will find that the orchidlike blooms secured in May will well reward you.

\section{IRIS ANGLICA.}

In 3 named varieties $\quad$ Doz. 100

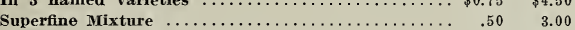

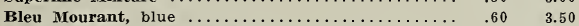

Mont Blanc, pure white, extra $\ldots \ldots \ldots \ldots \ldots \ldots \ldots . .45 \quad 2.50$

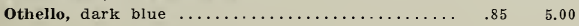

\section{THE IRIS HISPANICA.}

If planted around the end of September and given good winter protection, produces orchidlike flowers of remarkable beauty.

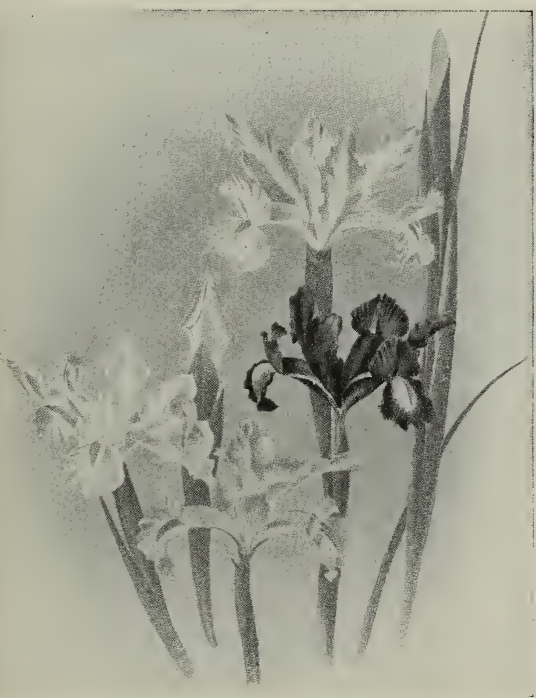

\section{IRIS HISPANICA.}

In 6 named varieties $\ldots \ldots \ldots \ldots \ldots \ldots \ldots \ldots$

Alex von Humboldt, indigo blue $\ldots \ldots \ldots \ldots \ldots$

Belle Chinoise, deep yellow

$\$ 0.20 \$ 1.10$
British Queen, pure white

Doz. 100 .

Chrysolora, pale yellow $\ldots \ldots \ldots \ldots \ldots \ldots \ldots \ldots$

Darling, dark blue $\ldots \ldots \ldots \ldots \ldots \ldots \ldots \ldots \ldots$

Leander, deep yellow $\ldots \ldots \ldots \ldots \ldots \ldots \ldots \ldots$

Louise, pearl color $\ldots \ldots \ldots \ldots \ldots \ldots \ldots \ldots \ldots$

Marie, blue $\ldots \ldots \ldots \ldots \ldots \ldots \ldots \ldots \ldots \ldots \ldots \ldots \ldots \ldots \ldots$

Mixed

\section{TUBEROUS BEGONIAS.}

All Begonias are splendid potplants and are unsurpassed for growing outdoors.

\section{SINGLE BEGONIAS.}

\begin{tabular}{|c|c|c|c|}
\hline Scarle & & $\begin{array}{l}\text { Doz. } \\
\$ 0.50\end{array}$ & $\begin{array}{l}100 . \\
\$ 3.00\end{array}$ \\
\hline Rose & $\cdots$ & .50 & 3.00 \\
\hline Orange & $\ldots \ldots \ldots \ldots \ldots \ldots \ldots \ldots \ldots \ldots \ldots \ldots \ldots$ & .50 & 3.00 \\
\hline White & 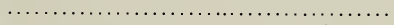 & .50 & 3.00 \\
\hline ellow & 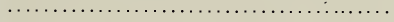 & .50 & 3.00 \\
\hline opper & & .50 & \\
\hline
\end{tabular}

\section{DOUBLE BEGONIAS.}

Orange $\ldots \ldots \ldots \ldots \ldots \ldots \ldots \ldots \ldots \ldots \ldots \ldots \ldots \ldots \ldots \ldots \$ 0.70 \quad \$ 4.00$

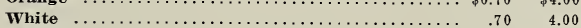

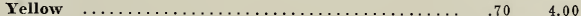

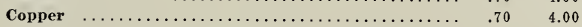

\section{BEGONIA CRISPA.}

New "Frilled" Begonia.

fringed.

The petals of this Begonia are fimbriated and wonderfully All colors mixed $\ldots \ldots \ldots \ldots \ldots \ldots \ldots \ldots \ldots \ldots \ldots \ldots \$ 1.00 \quad \$ 6.00$

\section{BEGONIA CRISTATA New bearded Begonias}

Produce large flowers of great substance and size and each petal is ornated with a conspicuous crest on the centre. Doz. 100 .

All colors mixed $\$ 1.00 \$ 6.00$

\section{CONVALLARIA or LILY OF THE VALLEY.}

Directions for forcing Lily of the Valley in your house.

The Berlin crowns are the best for early forcing. Dutch crowns are for late forcing. Both will do nicely outdoors as well-in that case plant in spring.

They can be easily forced in pots. Put about two inches of soil in a pot, put the bunch in, cut the string which keeps the crowns tied and fill up with soil in such a way that the crowns show slightly.

Keep them in a heated room, water daily and cover them with another flower pot so as to make the crowns start growing. After three or four weeks take the top pot away, give the crowns the full light and they will flower nicely after a month or so.

Give the Dutch crowns the same treatment, only force them slowly, do not give them as much heat as the Berlin crowns.

Plant the Berlin and Dutch Lily of the Valley as soon as you get them. $\quad$ Doz. 100

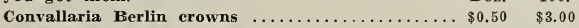
Convallaria Duteh erowns $\ldots \ldots \ldots \ldots \ldots \ldots \ldots \ldots \ldots . .40 \quad 2.25$

From Philadelphia, Pa.-

"Specimens of your Tulips were received-many thanks. The Tulips we purchased from you were the finest we have ever had and were much admired by all who saw them. Kindly send me a catalogue of the different flowers you carry; also price list." F. W. K., 5-13-15.

From Swarthmore, Pa.- "Trust next order will equal last for quality."

"We are very well satisfied with the Bulbs we purchased from you last season, and we trust that the order we have given to your salesman for next season will be of same good quality." S. \& L., 4-29-13. 


\section{GLADIOLUS}

Though the Gladiolus likes the sun and prefers good depth of light soil, well drained, it can readily be grown with success under any ordinary conditions.

Plant about four inches apart and five inches deep, for an average size bulb.

As they bloom from June on, they can be used to good advantage in rose or pæony beds; particularly if you arrange for a succession of bloom by starting early in May and planting each couple of weeks until the end of June. In this case you will have a beautiful mass of bloom until nearly October-but a short time before the yellowing of the foliage warns you that it is time to take up the bulbs and store them in the cellar, till next spring.

Doz. $100 . \quad 1000$.

America, bright pink, large flower $\ldots \ldots \ldots . \$ 0.40 \quad \$ 2.25 \quad \$ 17.00$

Brenchleyensis, scarlet, extra bulbs $\ldots \ldots \ldots \quad .47 \quad 2.75 \quad 20.00$ 1st size bulbs $\ldots \ldots \ldots \ldots \ldots . .35 \quad 2.00 \quad 15.00$

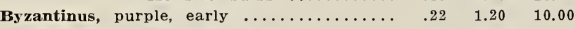

Colvilli alba (The Bride), white $\ldots \ldots \ldots \ldots, \quad .22 \quad 120$

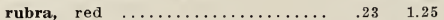

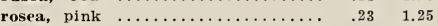

Childsi, mixed $\ldots \ldots \ldots \ldots \ldots \ldots \ldots \ldots \ldots \ldots, \quad .35 \quad 2.00$

good varieties named ............ $1.00 \quad 6.00$

Gandavensis Type, red and yellow $\ldots \ldots \ldots, \quad .35 \quad 2.00$ mixed, all colors $\ldots \ldots \ldots \ldots \ldots+.35 \quad 2.00$ named varieties ............. $.70 \quad 4.00$

Gelria, dark blue $\ldots \ldots \ldots \ldots \ldots \ldots \ldots \ldots, 1.00 \quad 6.00$

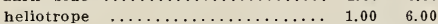

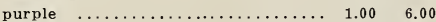

bright rose $\ldots \ldots \ldots \ldots \ldots \ldots \ldots \ldots, 1.00 \quad 6.00$

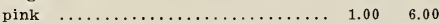

violet $\ldots \ldots \ldots \ldots \ldots \ldots \ldots \ldots \ldots \ldots, 1.00 \quad 6.00$

yellow. $\ldots \ldots \ldots \ldots \ldots \ldots \ldots \ldots \ldots, 1.40 \quad 8.00$

all colors mixed ............... $.70 \quad 4.00$

Groff's Hybrids, extra ................ $.70 \quad 4.00$

Hollandia, orange-yellow, large, new $\ldots . . \quad .50 \quad 3.00$

Lemoine, named varieties .............. $1.00 \quad 6.00$ Bar. Jos. Hulot, deep violet blue..
Marie Lemoine, creamy-white with salmon-pink .................

superfine mixed $\ldots \ldots \ldots \ldots \ldots \ldots$.

Nanus Ackermanni, orange-red ...........

Delicatissima (Blushing Bride) bright pink $\ldots \ldots \ldots \ldots \ldots \ldots$

Fairy Queen, carmine red $\ldots \ldots \ldots$

Peach Blossom, soft rose .........

mixed, all colors...$\ldots \ldots \ldots \ldots \ldots$.

Nanceianus, in named varietie superfine mixed

\section{.70}

4.00

$\begin{array}{lll}.50 & 3.00 & 24.00\end{array}$

$\begin{array}{lll}.35 & 2.00 & 15.00\end{array}$

$.28 \quad 1.50$

$.22 \quad 1.20$

$22 \quad 1.20$

$.35 \quad 2.00$

$.18 \quad 1.00$

$1.75 \quad 10.50$

$70 \quad 4.00$

Princeps, American novelty, large Amaryllis like flower, brilliant deep scarlet, with yellowish-white blotch $\ldots \ldots \ldots \ldots \ldots$. $\begin{array}{lll}75 & 4.50 & 35.00\end{array}$
Ramosus, Formosissimus, scarlet, white striped $\ldots \ldots \ldots \ldots \ldots \ldots$ Non plus Uitra, bright scarlet, superfine mixture $\ldots \ldots \ldots \ldots, \quad .35 \quad 2.00$

\section{NEWER AND NEWEST VARIETIES.} Doz. 100.1000

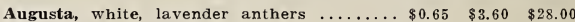

Bedenia, true lavender, not too blue, big well expanded flowers, a real beauty, Each, 75 cts. ................. 8.00

$15.00 \quad$ Each, 75 cts. $\ldots \ldots \ldots \ldots \ldots \ldots \ldots \ldots \ldots \ldots \ldots \ldots \ldots$
30.00 white blotch ................. $5.00 \quad 30.00$

Europa, large snowy-white flowers on vigorous elegant stems $\ldots \ldots \ldots \ldots \ldots \ldots, 3.00 \quad 18.00$

Francis King, scarlet $\ldots \ldots \ldots \ldots \ldots \ldots \ldots \ldots, \quad .75 \quad 4.50 \quad 35.00$

Glory of Noordwijk, sulphur-yellow ........ Each $\$ 3.00$

Halley, brilliant orange-red, yellow blotch

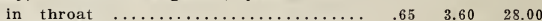

30.00 Lily Lehmann, very delicate rose, passing to white, large flowering variety. Exceedingly charming $\ldots \ldots \ldots \ldots \ldots \ldots \ldots \ldots \ldots$

Liebesfeuer, fiery red orange shaded, lower petals are striped violet-brown. Ea., $\$ 1.25 \quad \ldots \ldots \ldots \ldots \ldots \ldots \ldots \ldots \ldots \ldots \ldots \ldots \ldots \ldots \ldots+14.00$

Niagara, light yellow, deeper yellow in throat. Large open flowers on strong

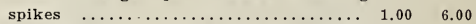

Panama, finest pink, flowers are large and wide open and the color of glowing mauve rose is certainly unique $\ldots \ldots \ldots, 2.00 \quad 12,00$

Pink Beauty, pink with small dark blotch. The earliest Gladiolus $\ldots \ldots \ldots \ldots \ldots \ldots, \quad .65 \quad 3.60 \quad 28.00$

Pink Perfection, light apple-blossom, the lower petals are reflexed lilac. Ea., .35 $3.75 \quad 21.00$

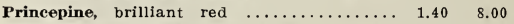

Willy Wigman, creamy-white, with crimson blotches on lower petals ........... $1.00 \quad 6.00$
Each \$0.30; Dozen, \$3.00.

SPIRAEA PHILADELPHIA is a marvel in lavender-pink, and a perfect grower. A striking novelty: for the first time introduced to the market. A cross between Astilbe hybr. Peach Blossom and Astilbe Arendsi, combining all the good capacities of both. The foliage of rich green color is like the old Spiraea Japonica. Elegant flowers of Catleya-color: nice lilac rose with silvery reflex, hereto unknown in forcing Spiraea. Forces at the same time as Queen Alexandra. Each, $\$ 0.75$; Per dozen, $\$ 7.00$.

AVALANCHE. Award of merit Royal Horticultural Society, London (Votes, unanimous). A good pure white variety obtained as the result of a cross between Spiraea compacta multifiora and Astilbe chiniensis. The flowers have the same feathered habit that has made the pink forms so popular. Each, $\$ 0.30$; Per dozen, $\$ 3.00$.

QUEEN ALEXANDRA (IMPROVED). A deep pink flower. Has all the good capacities of the common Queen Alexandra; the color is, however, more constant and a better pink.

RUBENS. Deep pink, forces as early and as easily as Gladstone. Each, $\$ 0.40$; Per dozen, $\$ 4.00$. Each, \$0.75; Per dozen, $\$ 7.00$.

QUEEN ALEXANDRA, the newest pink, has created much sensation among all growers; it combines together with its deep rosy pink the perfect growing and easy forcing of the Spiraea Gladstone.

Each, $\$ 0.20$; Per dozen, $\$ 2.00$

GLADSTONE, The growers of the continent were not surprised when, as the result of our long experience as Spiraea specialists, it was possible to offer a new white Spiraea, which was a perfect grower of extra free flowering habit and which forced easily. This white-the Gladstone Spiraea-is standard for highest class use in Europe, and has has been bought by many of the best florists in America, all of whom express their highest satisfaction. Each. Dozen.

Peach Blossom, clear pink .............. $\$ 0.20 \$ 2.00$

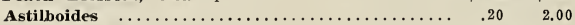

$\begin{array}{llll} & \text { floribunda } \ldots \ldots \ldots \ldots \ldots \ldots \ldots \ldots \ldots \ldots \ldots & .20 & 2.00\end{array}$

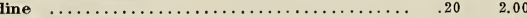

Comparta multiflora $\ldots \ldots \ldots \ldots \ldots \ldots \ldots \ldots \ldots \ldots \ldots . .20 \quad 2.00$

From Nelsonville, N. J.-“1913 test order leads to 1914 entire order."

"Your letter answering questions about lifting Darwin Tulips received, for which I thank you very much. I am sending you my ENTIRE ORDER for Tulips, as those I bought from your firm last year were superior to those I bought elsewhere. Am also sending a small order for a friend." E. N. N., 6-24-14. 


\section{IMPORTED BULBS}

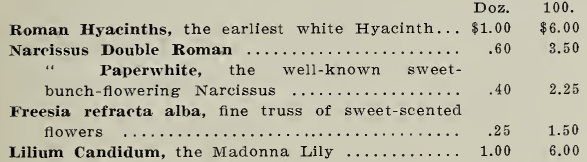

\section{LILIUM AURATUM GOLD-BANDED LILY.}

A beautiful Lily from Japan, the flowers are white, with crimson dots and a golden band through the centre of each petal. We send these Lilies beginning of March until April.
Doz. 100

Top size Bulbs $\ldots \ldots \ldots \ldots \ldots \ldots \ldots \ldots \ldots \ldots \ldots \ldots, \$ 0.40 \quad \$ 4.00$

First size $\ldots \ldots \ldots \ldots \ldots \ldots \ldots \ldots \ldots \ldots \ldots \ldots \ldots \ldots . .30 \quad 3.00$

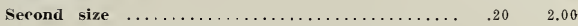

\section{TUBEROSES THE PEARL.}

These Tuberoses are imported by us from one of the best growers, and we can therefore guarantee these bulbs to be the very best obtainable. We, send the Tuberoses from the Beginning of March until half of April. We should recommend our customers to take a trial with these Bulbs which produce pure white flowers with a very nice odor.

Per dozen, $\$ 0.50$; per hundred, $\$ 3.00$.

\section{MISCELLANEOUS BULBS}

We have cut down this list to only the most popular kinds of miscellaneous bulbs.

Being specialists in bulbs we do not like to make the impression on you that ours is a catalogue from which you can order just anything you find in any other ordinary price-list. What we offer we grow and supply to you direct from our own fields.

Doz. 100

Allium, azureum, heaven-blue ............ $\$ 0.85 \$ \$ 5.00$

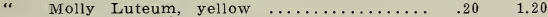

" Neapolitanum $\ldots \ldots \ldots \ldots \ldots \ldots \ldots \ldots \ldots . .20 \quad 1.20$

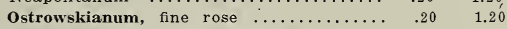

Chionodoxa gigantea, Glory of the Snow, blue.... $\quad .35 \quad 2.00$ Luciliae, Glory of the Snow, blue with

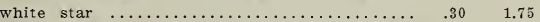

Chionodoxa Sardensis. Glory of the snow; fine

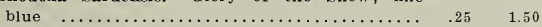

Eranthis Hyemalis, yellow, very early ......... 15

Erythronium Americanus, yellow ...................... $1.35 \quad 8.00$

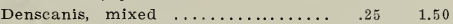
album, white $\ldots \ldots \ldots \ldots . .25 \quad 1.50$ purpureum, purple $\ldots . .35 \quad .35 \quad 2.00$ roseum, rose $\ldots \ldots \ldots \ldots . .250 .150$

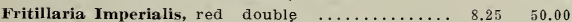

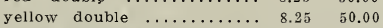
gold striped (single) $\ldots \ldots \ldots, 3.50 \quad 20.00$ yellow (single) $\ldots \ldots \ldots \ldots, 2.50 \quad 15.00$ aurora, red (single) $\ldots \ldots \ldots 2.50 \quad 15.00$ crown upon crown (single), $2.00 \quad 12.00$ red (single) $\ldots \ldots \ldots \ldots \ldots .1 .30 \quad 8.00$

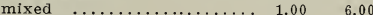

Doz. 100.

ritillaria meleagris, mixed, spring flowering.... $\$ 0.20 \$ 1.20$ Ixia, mixed $\ldots \ldots \ldots \ldots \ldots \ldots \ldots \ldots \ldots \ldots \ldots \ldots . .15 \quad .80$ Muscari Botryoides, blue, grape Hyacinths $\ldots \ldots . \quad .15 \quad .80$ white, grape Hyacinths .... $.20 \quad 1.20$

Plumosus, violet feather Hyacinths .... $.20 \quad 1.20$

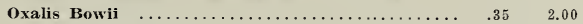

"Cernua, yellow ................... $20 \quad 1.20$

Cernua, fl. pl., double yellow ........... $.40 \quad 2.40$

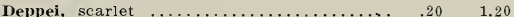

Superfine Mixed $\ldots \ldots \ldots \ldots \ldots \ldots \ldots \ldots \ldots . .20 \quad 1.20$

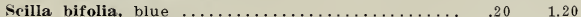

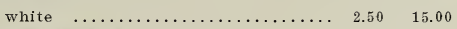

campanulata alba, white .............. $20 \quad 1.20$

" " blue $\ldots \ldots \ldots \ldots \ldots \ldots \ldots \ldots . .20 \quad .20$

sibirica, blue $\ldots \ldots \ldots \ldots \ldots \ldots \ldots \ldots \ldots \ldots \ldots .20 \quad 1.20$

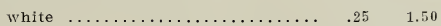

Snowdrops (Galanthus Nivalis). These little white heralds of the spring are simply lovely. The snow has hardly left your lawn and 10 ! they push up their tiny heads to ring in the time which inspires the whole flower-world with new life. And they don't require any special attention either. They just invite you to look at them and enjoy spring.

Snowdrops, single $\ldots \ldots \ldots \ldots \ldots \ldots \ldots \ldots \ldots \ldots \ldots+20 \quad \$ 1.20$

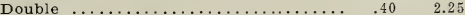

Elwesii (large single flowers) $\ldots \ldots \ldots . .20 \quad 1.20$

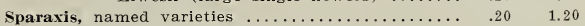

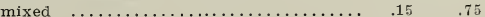

From Covington, Tenn.- "Better results from ours second year, than from others first year."

"Two years ago I gave your firm an order and I want to say that nothing has ever been seen here like the results I got. Especially the Hyacinths and Tulips. My Liliums did not do so well, owing, I think, to weather conditions. Last year I mislaid your catalog and ordered from other florists with indifferent results. In fact, the bulbs from your firm did better the second year than the first year bulbs from other fiorists. Several parties have asked me about ordering from you and I think I can secure you several responsible customers at this place." S. S., 5-26-14.

"Wakru" means dependable varieties. We catalog no experiments. 


\section{Paeony-Flowered Dahlias}

This is a new class of Dahlias of very large size. The flowers are borne on long, stout stems and are especially well fit for decoration.

The plants produce an effective display in the garden. The new varieties introduced by our firm are the very best, and many of them were awarded certificates and awards of merit. We send these roots in spring so that our customers can plant them in May and have no bother to keep the roots free of frost during winter.

\begin{tabular}{|c|c|c|c|}
\hline & Each. & & Each. \\
\hline ie, salmon pink. Award of merit......... & & Kaiserin Augusta Victoria, creamy-white .. & \\
\hline ttner, blush rose, with salmon tint. Award & & King Edward, deep purple, unique shade $\ldots \ldots \ldots \ldots \ldots$ & .45 \\
\hline$\ldots \ldots \ldots \ldots \ldots \ldots \ldots \ldots$ & .35 & King Leopold, canary yellow $\ldots \ldots \ldots \ldots \ldots \ldots \ldots \ldots \ldots$ & .20 \\
\hline Cresar, canary yellow. 1st class certificate $\ldots \ldots \ldots \ldots \ldots$ & .55 & H. J. Lovink, mauve shaded. 1st class certificate $\ldots \ldots \ldots$ & .50 \\
\hline Cecilia, creamy-white. 1st class certificate $\ldots \ldots \ldots \ldots \ldots$ & .55 & La Riante, soft shade of mauve-pink $\ldots \ldots \ldots \ldots \ldots \ldots$ & .20 \\
\hline Dr. W. K. v. Gorkum, white, rosy shaded $\ldots \ldots \ldots \ldots \ldots$ & .20 & Mannheim, soft orange-red. 1st class certificate ... & .20 \\
\hline Dr. Peary, dark mahogany, velvety shaded. Award of & & Merveille, orange-yellow, marvellous form ...... & .25 \\
\hline 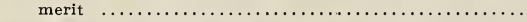 & .55 & Miss Gladys Dawson, & .20 \\
\hline Duke Henry, rich brilliant deep crimson $\ldots \ldots \ldots \ldots \ldots \ldots$ & .20 & Montblanc, pure white $\ldots \ldots \ldots \ldots \ldots \ldots \ldots \ldots$ & .60 \\
\hline Geisha, scarlet and gold, the most sensational dahlia of & & osy, white striped $\ldots \ldots \ldots \ldots \ldots \ldots$ & .20 \\
\hline all. 1st class certificate ..... & .55 & $\mathbf{n}$, orange-yellow $\ldots \ldots \ldots \ldots \ldots \ldots \ldots \ldots$ & .30 \\
\hline Germania, bright glowing crimson-scarlet $\ldots$. & .20 & Queen Alexandra, sulphur-yellow. 1st class certificate ... & .35 \\
\hline Glory of Baarn, soft pink. 1st class certificate .... & .20 & 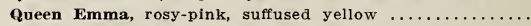 & .20 \\
\hline H. Hornsveld, soft salmon, elegant form $\ldots \ldots \ldots$ & .30 & Queen Wilhelmina, pure white $\ldots \ldots \ldots \ldots \ldots \ldots \ldots \ldots$ & .20 \\
\hline Hortulanus Budde, bright orange-red. Award of merit ... & 1.00 & 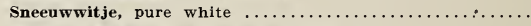 & .20 \\
\hline Hugo de Vries, bronzy-orange $\ldots \ldots \ldots \ldots \ldots \ldots \ldots \ldots$ & .20 & Sherlock Holmes, mauve, splendid form $\ldots \ldots \ldots \ldots \ldots$ & 1.20 \\
\hline Isadora Duncan, pale salmon. & .30 & Vesta, pale yellow, salmon rose shaded $\ldots \ldots \ldots \ldots \ldots \ldots$ & .35 \\
\hline
\end{tabular}

\section{New Paeony-Flowered Dahlias}

America, apricot-orange. 1st class certificate ......... $\$ 4,00$ Avalanche, pure white, the best white in this class. Award

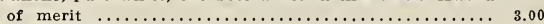
Fraulein Budde, soft pink, free flowering. Award of merit, 2.00
Electra, bluish-mauve, grows very erect above the foliage, free flowering. 1st class certificate ............. 2.00 Loveliness, pale lilac, white shaded. Award of merit .... 3.00 Painted Lady, pale rose. Award of merit .......... 3.00

\section{Paeony-Flowered Dahlias New Novelties}

Chatenay, color similar to the well-known Chatenay rose, blooms held erect on good stiff stalk. First class cer-

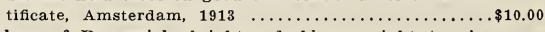

Duchess of Brunswick, bright red, blooms eight to nine inches across, the outside of the florets being apricot. First class certificate National Dahlia Society and Award of merit, R. H. S., London, Sept., $1913 \ldots \ldots \ldots 12.00$
Each.

Mrs. J. C. Vaughan, lovely bright, yet clean yellow flowers, eight inches across, with incurved irregular florets of the Cactus type, very attractive, good stalk and substance. First class certificate. National Dahlia Society and Award of merit, R. H. S., London, Sept.,

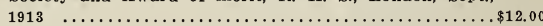

\section{Paeony-Decorative Dahlias}

Alice Roosevelt, mauve shaded $\ldots \ldots \ldots \ldots \ldots \ldots \ldots \ldots \ldots 0.40$ Hortulanus Fiet, salmon, yellow centre, very large. 1st

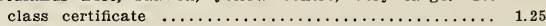
Hortulanus Witte, pure white. 1st class certificate ..... .45
Irs. Fleers, rosy-red. 1st class certificate Each Princess Juliana, pure white, free flowering, the best white for cutting. 1st class certificate ...............45 Zeppelin, mauve, perfect form. Award of merit $\ldots \ldots \ldots 1.25$

\section{New-Paeony Decorative Dahlias}

erch van Heemstede, pure yellow, free flowering. 1st

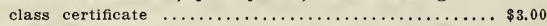
Great Britain, deep mauve, perfect form, very large flower.
1 st class certificate $\ldots \ldots \ldots \ldots \ldots \ldots \ldots \ldots \ldots \ldots \ldots \ldots 4.50$

Each.

Leo XIII, deep yellow, remarkable form, very attractive.

Award of merit, 1913. 1st class certificate, $1913 \ldots \ldots .50$

From Salem, N. J.- "So healthy and fine-wants more."

"In response to our order of the $19 \mathrm{th}$, the hundred Tulip Bulbs came in good condition. They seem so healthy and fine, and we find we will have space for one hundred more, so are enclosing stamps for one hundred more, asking that you send the same kind-Murillo (double) Tulips-as soon as possible." D. S. C., 10-23-14.

From Urbana, Ohio.- "Sure they will bloom well."

"I received the order of bulbs yesterday. They are fine, large bulbs-the best I have ever had. I thank you very much for the extra ones you added. I am sure there will be no failure in blooms in the spring.' Miss L. E. T., 10-6-14. 


\section{WAKRU SEED AND BULB CO. 200 Walnut Place}

PHILADELPHIA, PA.

Date

Name, (Mr., Mrs. or Miss)

Street, P. O. Box or

Rural Delivery

Post Office, ( $\left.\begin{array}{c}\text { If different } \\ \text { from P. O. }\end{array}\right)$

Country,

State

Amount Enclosed $\begin{gathered}\text { State whether P. O. Order } \\ \text { Express Money Order, Draft, } \\ \text { Postage Stamps or Cash. }\end{gathered}$

\section{PLEASE DO NOT WRITE HERE,}

but use separate paper for communications. We will with much pleasure send our catalogue to any of your friends whose address you would kindly mention to us on opposite side.

Orders from unknown correspondents without satisfactory commercial rating should be accompanied by a remittance to cover the order or by satisfactory reference.

All accounts are due 60 days following delivery; they are payable in PHILADELPHIA; the drawing of bills does not annul the above condition.

Claims as to the quality of the goods cannot be entertained, unless made immediately on receipt of same.

We give no warranty, express or implied, and will not be in any way responsible for the results of planting or forcing of any bulbs and roots we sent out; we guarantee all varieties to be true to name and description.

By placing orders, buyers are considered to agree with these terms.

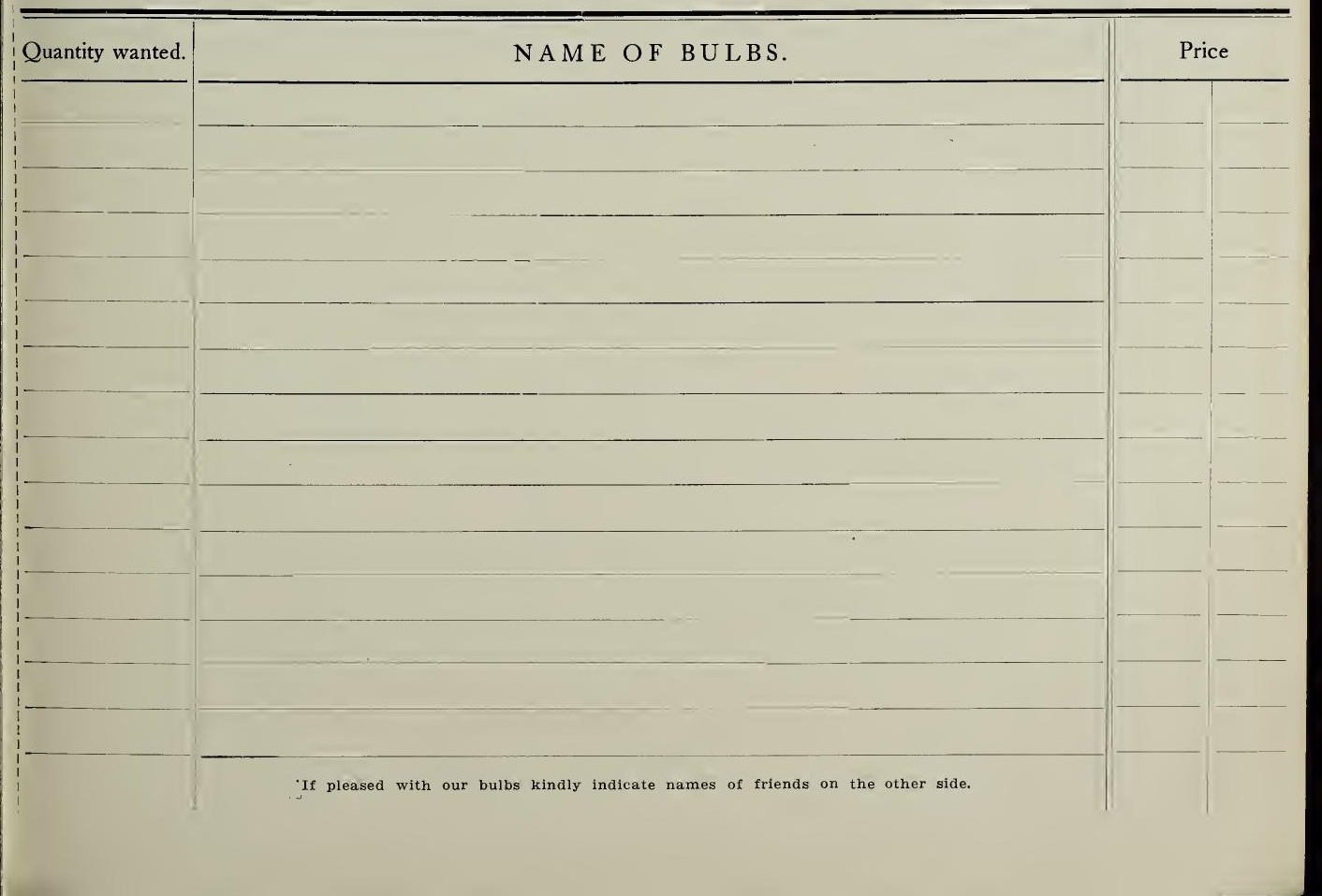


Names and addresses of Friends, who are interested in bulbs. 


\section{A LESSON IN BUYING}

TJ HEN a friend of yours complains that something he bought is no good, you come back quickly with the remark, "Why didn't you buy the trade-marked article? You know that is good. Why take chances on something that the maker don't even put his name on?"

Which is truth. A trade-marked article must be good, or the trade name is its own undoing.

Trade marks and trade names make it easier to remember the article and its origin - the maker and seller of unworthy goods want you to forget.

If a man puts out three grades of goods, he applies his trademark to the best and puts his whole soul back of that line. He must maintain quality or go out of business.

There are many grades of Dutch Bulbs. Even at the finest nurseries in Holland the bulbs require sorting. On the best grade only-big mother bulbs, full of vitality-we put the Wakru Girl trade mark. For five years we have been selling bulbs in America with this trade mark and the volume of business has grown because no one who has planted Wakru Bulbs one year was satisfied to plant any other bulbs next year.

Experts grow these bulbs, experts sort out the best bulbs for the Wakru packages, experts pack them right at the bulb fields in

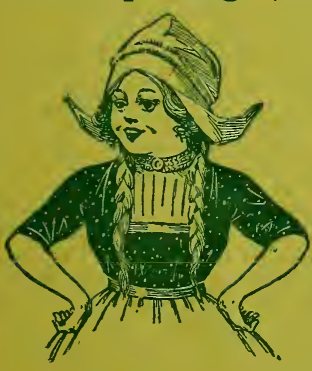
Holland. You are surer that Wakru Bulbs are true to name and color, you are surer of a larger quantity of larger size flowers -if you get "Wakru" Bulbs. They come to your home right in the original packages into which they are put in Holland by our experts.

Why take chances on bulbs without a trade name-without a trade mark to identify them.

Give a test order for Wakru Bulbs-make comparisons with the best other bulbs you know of. We abide by your judgment. Next year when you see the larger blooms and more of themyou will determine to buy nothing but Wakru Bulbs. 


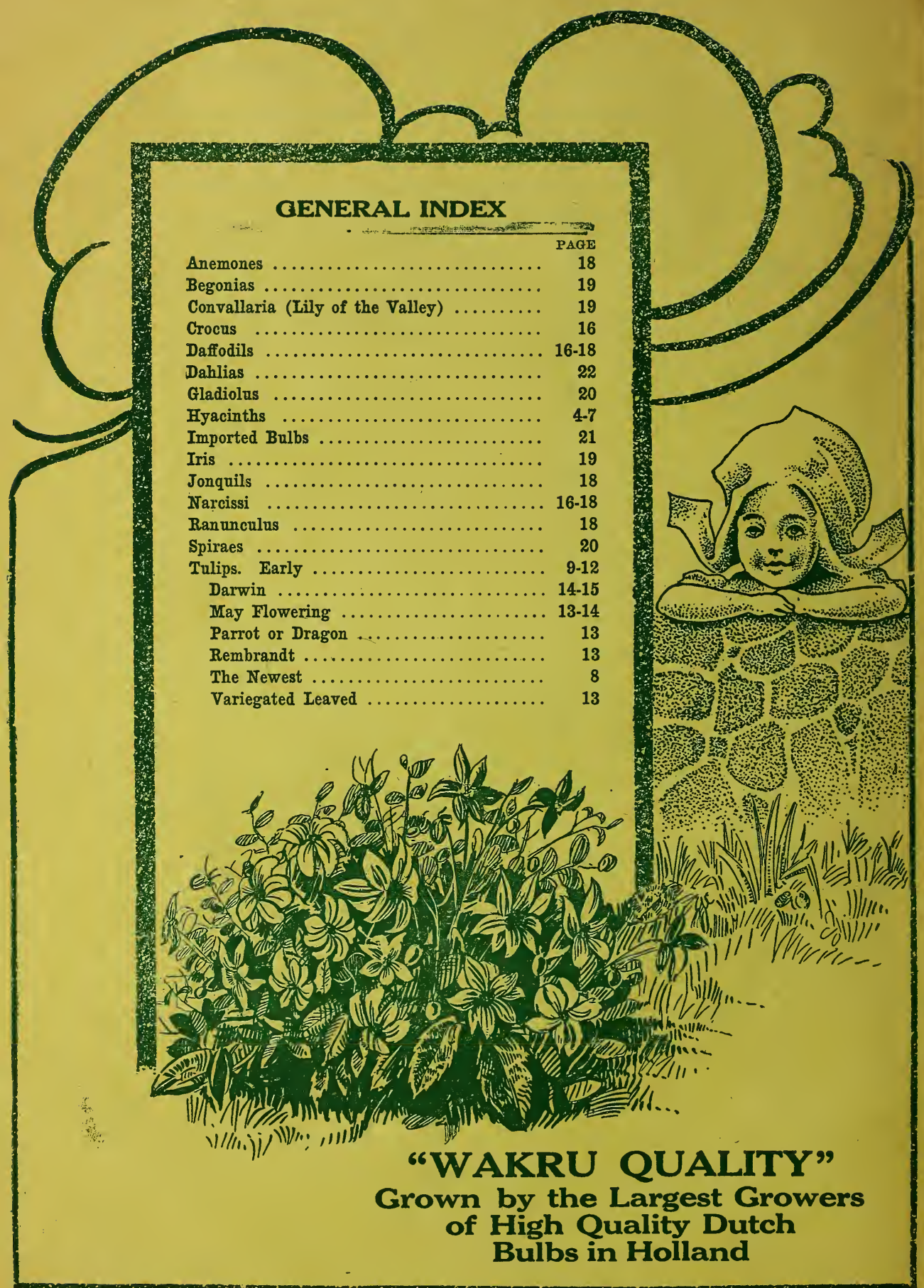

